\title{
ROA opleidingsindeling 2015
}

Citation for published version (APA):

Kuenn, A., Dijksman, S., \& Fouarge, D. (2016). ROA opleidingsindeling 2015. ROA. ROA Technical Reports No. 003 https://doi.org/10.26481/umarot.2016003

Document status and date:

Published: 01/01/2016

DOI:

10.26481/umarot.2016003

Document Version:

Publisher's PDF, also known as Version of record

\section{Please check the document version of this publication:}

- A submitted manuscript is the version of the article upon submission and before peer-review. There can be important differences between the submitted version and the official published version of record.

People interested in the research are advised to contact the author for the final version of the publication, or visit the DOI to the publisher's website.

- The final author version and the galley proof are versions of the publication after peer review.

- The final published version features the final layout of the paper including the volume, issue and page numbers.

Link to publication

\footnotetext{
General rights rights.

- You may freely distribute the URL identifying the publication in the public portal. please follow below link for the End User Agreement:

www.umlib.nl/taverne-license

Take down policy

If you believe that this document breaches copyright please contact us at:

repository@maastrichtuniversity.nl

providing details and we will investigate your claim.
}

Copyright and moral rights for the publications made accessible in the public portal are retained by the authors and/or other copyright owners and it is a condition of accessing publications that users recognise and abide by the legal requirements associated with these

- Users may download and print one copy of any publication from the public portal for the purpose of private study or research.

- You may not further distribute the material or use it for any profit-making activity or commercial gain

If the publication is distributed under the terms of Article $25 \mathrm{fa}$ of the Dutch Copyright Act, indicated by the "Taverne" license above, 
ROA opleidingsindeling 2015

\section{ROA Technical Report}

ROA-TR-2016/3

Researchcentrum voor Onderwijs en Arbeidsmarkt | ROA Research Centre for Education and the Labour Market | ROA 


\section{ROA opleidingsindeling 2015}

ROA-TR-2016/3

April 2016

Research Centre for Education and the Labour Market Maastricht University P.O. Box 616, 6200 MD Maastricht, The Netherlands $\mathrm{T}+31433883647 \mathrm{~F}+31433884914$

secretary-roa-sbe@maastrichtuniversity.nl www.roa.nl 


\section{Inhoudsopgave}

Pagina

Inhoudsopgave

1

1 Inleiding

2

2 Aanpak nieuwe opleidingsindeling

2

2.1 Opleidingsniveau

2

2.2 Opleidingsrichting

3 Conclusie en vooruitblik 


\section{$1 \quad$ Inleiding $^{1}$}

Om de kosteneffectiviteit van de dataverzameling van de Enquête Beroepsbevolking (EBB) te vergroten is deze door het CBS onderworpen aan een herontwerp. Vanaf 2013 wordt het beroep niet meer waargenomen en ingedeeld volgens de Standaard Beroepenclassificatie 1992 (SBC 1992) maar alleen nog volgens de ISCO 2008 en de opleidingsachtergrond wordt niet meer waargenomen en ingedeeld volgens de Standaard Opleidingsindeling (SOI 2003) maar volgens de ISCED 1997. Dit dwingt het ROA zowel haar indeling van beroepen als opleidingen te herzien.

Vanaf 2014 gebruikt het ROA binnen het Project Onderwijs-Arbeidsmarkt (POA) de Beroepenindeling ROA CBS 2014 (afgekort BRC 2014). ${ }^{2}$ In deze notitie wordt de indelingen van opleidingen - de ROA opleidingsindeling 2015 - op basis van de in de EBB beschikbare ISCED codes toegelicht.

\section{Aanpak nieuwe opleidingsindeling}

\subsection{Opleidingsniveau}

ISCED 1997 is de internationale onderwijsclassificatie van de UNESCO. Het onderscheidt 7 hoofdgroepen oftewel levels (ISCED 0-6), maar is geen zuivere indeling naar onderwijsniveau zoals wij die kennen vanuit de SOI. Zo overlappen de ISCED levels 3, 4, 5 en 6 elkaar in termen van onderwijsniveau en omvat bijvoorbeeld ISCED code $3 \mathrm{~A}$ naast mbo 4 ook havo/vwo opleidingen. Voor de indeling naar opleidingsniveau wordt om die reden aangesloten bij de Code Type Opleiding (СTO) van het CBS dat beschikbaar is gesteld in de EBB.

Een belangrijk uitgangspunt bij de nieuwe indeling van opleiding naar niveau is de wens van de POA begeleidingscommissie om meer onderscheid te maken in de niveaus van het mbo. De nieuwe indeling onderscheidt dan ook 6 opleidingsniveaus:

1. basisonderwijs en (v)mbo

2. havo/vwo

3. $\operatorname{mbo} 2 / 3$

4. $\operatorname{mbo} 4$

5. hbo

6. wo

1 Dit technisch rapport is tot stand gekomen in het kader van het Project OnderwijsArbeidsmarkt (POA):

http://roa.sbe.maastrichtuniversity.nl/?portfolio=poa-project-onderwijs-arbeidsmarkt-2

2. http://roastatistics.maastrichtuniversity.nl/AIS/pdf/Beroepenindeling\%20ROACBS\%202014.pdf

2 
In bijlage 1 wordt een overzicht gegeven van de onderliggende CTO en ISCED 1997 level codes bij deze niveau indeling.

\subsection{Opleidingsrichting}

De ISCED1997 onderscheidt studierichtingen naar zogenaamde broad fields (eerste digit) en daarbinnen (narrow) fields (eerste twee digits). In Eurostat verband is deze indeling verder verfijnd naar detailed fields of education and training (drie digits).

Er worden 9 hoofdrichtingen onderscheiden:

0 - General programmes

1 - Education

2 - Humanities and arts

3 - Social sciences, business and law

4 - Science

5 - Engineering, manufacturing and construction

6 - Agriculture

7 - Health and welfare

8 - Services

Voor de indeling van de ROA opleidingen naar richting zijn drie belangrijke uitgangspunten gehanteerd:

- Het bieden van voldoende detail voor de gebruikers, rekening houdend met de beheersbaarheid van de indeling en datavulling in de EBB.

- De herkenbaarheid van de opleidingen door gebruikers.

- De aansluiting tussen opleidingen en beroepen.

Wij onderscheiden op het laagste detailniveau in totaal 96 opleidingstypen inclusief overig (combinaties van cto niveau en ISCED 3 digit detailed field). Voor het havo/vwo-niveau wordt er geen onderscheid gemaakt naar richting. Voor de andere niveau's wordt er een aantal opleidingstypen weergegeven. Er zijn 7 opleidingstypen op basisonderwijs en vmbo niveau, 21 op mbo 2/3 niveau, 21 op mbo 4 niveau, 26 op hbo niveau en 19 op wo niveau.

De volgende stap in de classificatie is dat er een clustering per niveau plaatsvindt. De clustering levert een categorie indeling op per opleidingsniveau. Voor de niveau's van het basisonderwijs en vmbo en havo/vwo is er geen categorie-indeling gemaakt. Voor het mbo hanteren we een vierdeling van categorieën te weten, groen, economie, techniek en zorg en welzijn. Met behulp van de "detailed field" informatie wordt bepaald tot welke van de vier mogelijke categorieën een opleidingstype behoort. Voor het ho maken we gebruik van een combinatie van zowel "detailed field" informatie en clustering in het beroepsdomein op basis van informatie over beroepsen opleidingsachtergrond van individuen uit de EBB. In bijlage 2 wordt een compleet overzicht gegeven van de samenhang tussen de verschillende opleidingstypen per opleidingscategorie, per opleidingsniveau, de ISCED1997 codering van de detailed fields en het aantal werkenden volgens de internationale definitie in de EBB in 2013 en 2014. Hierbij wordt het aantal werkenden weergegeven voor de combinaties met 
meer dan 10.000 werkenden in de EBB per jaar (kleinere aantallen worden met een '-' weergegeven). In bijlage 3 wordt nog meer inzicht gegeven over de onderliggende samenstelling van crebo/croho codes in de opleidingstypen en bijbehorende isced detailed fields. Wat de wo bachelor gediplomeerden betreft worden deze overeenkomstig de CBS bepaling van het opleidingsniveau samengenomen met de hbo bachelors. Hbo master gediplomeerden worden gelijk geschaald aan wo master gediplomeerden, eveneens conform de CBS bepaling van het opleidingsniveau.

\section{Indeling naar richting in het basisonderwijs en vmbo}

Voor het basisonderwijs en vmbo wordt alleen een onderscheid gemaakt in typen, zowel naar basisonderwijs als voor het vmbo naar leerweg en sectoren. Er wordt naast het basisonderwijs een 6-tal vmbo opleidingen onderscheiden aan de hand van de detailed field 3 digit ISCED richting:
1. basisonderwijs
2. vmbo economie
3. vmbo techniek
4. vmbo groen
5. vmbo zorg en welzijn
6. vmbo overig
7. vmbo tl/gl

\section{Indeling naar richting en categorie in het mbo}

Voor het mbo wordt uitgegaan van de 2 digit ISCED field, waarbij een verder verbijzondering naar 3 digit ISCED field plaats vindt bij grote opleidingen. Bij de naamgeving van de opleidingen is, in verband met de herkenbaarheid van de opleidingsnamen, aansluiting gezocht bij de naam van de onderliggende CREBO. De richtingsindeling op niveau 2/3 wijkt op twee punten af van die op niveau 4 omdat het opleidingsaanbod verschilt per niveau. Zo is er een opleidingstype onderwijs op niveau 4, maar niet op niveau 2/3. En is er een opleidingstype veiligheid op niveau 2/3 en niet op niveau 4.

Per niveau 2/3 en 4 wordt er een vierindeling van categorieën gemaakt van richting, te weten: groen, economie, techniek, zorg en welzijn. In de vijfde categorie overig komen grotendeels coderingen terecht als we alleen het opleidingsniveau weten en geen of te weinig informatie hebben over de opleidingsrichting.

Op niveau $2 / 3$ onderscheiden wij de volgende 5 opleidingscategorieën en 21 -typen:

$\begin{array}{lll}1 & \text { mbo } 2 / 3 \text { groen } & \text { mbo } 2 / 3 \text { voedsel, natuur en milieu } \\ 2 & \text { mbo } 2 / 3 \text { economie } & \text { mbo } 2 / 3 \text { commercieel, financieel en administratief } \\ 3 & \text { mbo } 2 / 3 \text { economie } & \text { mbo } 2 / 3 \text { detailhandel } \\ 4 & \text { mbo } 2 / 3 \text { economie } & \text { mbo } 2 / 3 \text { secretarieel } \\ 5 & \text { mbo } 2 / 3 \text { economie } & \text { mbo } 2 / 3 \text { informatica } \\ 6 & \text { mbo 2/3 economie } & \text { mbo } 2 / 3 \text { horeca } \\ 7 & \text { mbo } 2 / 3 \text { economie } & \text { mbo } 2 / 3 \text { recreatie, vrijetijd en sport } \\ 8 & \text { mbo } 2 / 3 \text { economie } & \text { mbo } 2 / 3 \text { facilitaire dienstverlening } \\ 9 & \text { mbo } 2 / 3 \text { economie } & \text { mbo } 2 / 3 \text { veiligheid }\end{array}$




\begin{tabular}{|c|c|c|}
\hline 10 & mbo $2 / 3$ techniek & mbo $2 / 3$ media en vormgeving \\
\hline 11 & mbo $2 / 3$ techniek & mbo $2 / 3$ werktuigbouwkunde en metaalbewerking \\
\hline 12 & mbo $2 / 3$ techniek & mbo $2 / 3$ technische installatie \\
\hline 13 & mbo $2 / 3$ techniek & mbo $2 / 3$ operator \\
\hline 14 & mbo $2 / 3$ techniek & mbo $2 / 3$ voertuigtechniek \\
\hline 15 & mbo $2 / 3$ techniek & mbo $2 / 3$ techniek overig \\
\hline 16 & mbo $2 / 3$ techniek & mbo $2 / 3$ bouw en infra \\
\hline 17 & mbo $2 / 3$ techniek & mbo $2 / 3$ transport en logistiek \\
\hline 18 & mbo $2 / 3$ zorg en welzijn & mbo $2 / 3$ gezondheidszorg \\
\hline 19 & mbo $2 / 3$ zorg en welzijn & mbo 2/3 maatschappelijke zorg \\
\hline 20 & mbo $2 / 3$ zorg en welzijn & mbo $2 / 3$ schoonheids- en haarverzorging \\
\hline 21 & mbo $2 / 3$ overig & mbo $2 / 3$ overig \\
\hline
\end{tabular}

Niveau 4 onderscheidt de volgende 5 opleidingscategorieën en 21 -typen:

\begin{tabular}{lll}
\hline 1 & mbo 4 groen & mbo 4 voedsel, natuur en milieu \\
\hline 2 & mbo 4 economie & mbo 4 commercieel, financieel en administratief \\
\hline 3 & mbo 4 economie & mbo 4 detailhandel \\
\hline 5 & mbo 4 economie & mbo 4 secretarieel \\
\hline 6 & mbo 4 economie & mbo 4 informatica \\
\hline 7 & mbo 4 economie & mbo 4 horeca \\
\hline 8 & mbo 4 economie & mbo 4 recreatie, vrijetijd en sport \\
\hline 9 & mbo 4 techniek & mbo 4 facilitaire dienstverlening \\
\hline 10 & mbo 4 techniek & mbo 4 media en vormgeving \\
\hline 11 & mbo 4 techniek & mbo 4 werktuigbouwkunde en metaalbewerking \\
\hline 12 & mbo 4 techniek & mbo 4 technische installatie \\
\hline 13 & mbo 4 techniek & mbo 4 operator \\
\hline 14 & mbo 4 techniek & mbo 4 voertuigtechniek \\
\hline 15 & mbo 4 techniek & mbo 4 techniek overig \\
\hline 16 & mbo 4 techniek & mbo 4 bouw en infra \\
\hline 17 & mbo 4 zorg en welzijn & mbo 4 transport en logistiek \\
\hline 18 & mbo 4 zorg en welzijn & mbo 4 onderwijs \\
\hline 19 & mbo 4 zorg en welzijn & mbo 4 maatschappelijke zorg \\
\hline 20 & mbo 4 zorg en welzijn & mbo 4 schoonheids- en haarverzorging \\
\hline 21 & mbo 4 overig & mbo 4 overig \\
\hline & & \\
\hline
\end{tabular}

Indeling naar richting in het hoger onderwijs

In tegenstelling tot het mbo zijn de opleidingen in het hoger onderwijs breder van aard. Daardoor is er sprake van een grotere uitwaaiering over beroepen. Voor de indeling naar opleidingstypen in het hoger onderwijs is om die reden een cluster analyse uitgevoerd op de EBB data, waarbij de ISCED narrow field (2 digit) richtingen voor het hoger onderwijs geclusterd zijn naar de beroepsklassen indeling uit de BRC 2014 classificatie. Dit moet er voor zorgen dat er een goede aansluiting ontstaat tussen prognoses naar opleiding en beroep in het prognosemodel van het ROA voor het Project Onderwijs Arbeidsmark (POA). Voor de naamgeving, en de herkenbaarheid, van de opleidingsrichtingen is indien mogelijk aansluiting gezocht bij de naam van de onderliggende $\mathrm{CROHO}$. Binnen het hbo worden de 26 opleidingstypen samengevoegd tot 7 categorieën. Voor het wo worden de de 19 opleidingstypen ook samengevoegd tot $7 \mathrm{~min}$ of meer vergelijkbare categorieën. 
Alleen de naamgeving voor een tweetal categorieën wijkt af. Zo onderscheiden we hbo economie t.o.v. wo economie en recht. Recht wordt bij wo in de naam van de categorie opgenomen aangezien wo recht een groter aandeel in wo economie en recht categorie heeft dan hbo recht in hbo economie. En voor het hbo spreken we van de gezondheidszorg in tegenstelling tot het wo waar we de zorg samenpakken in de term medisch. Ook in het ho wordt er een categorie overig vastgesteld, die wordt toegekend als alleen het niveau bekend is en geen of te weinig informatie over de richting.

In het hbo worden er 7 opleidingscategorieën en 26 -typen onderscheiden:

\begin{tabular}{|c|c|c|}
\hline 1 & hbo onderwijs & hbo leraar basisonderwijs \\
\hline 2 & hbo onderwijs & hbo leraar algemene vakken \\
\hline 3 & hbo onderwijs & hbo leraar beroepsgerichte vakken \\
\hline 4 & hbo taal en cultuur & hbo kunst \\
\hline 5 & hbo taal en cultuur & hbo communicatie \\
\hline 6 & hbo taal en cultuur & hbo journalistiek \\
\hline 7 & hbo economie & hbo bedrijfseconomie \\
\hline 8 & hbo economie & hbo marketing en commerciele economie \\
\hline 9 & hbo economie & hbo accountancy en financiën \\
\hline 10 & hbo economie & hbo bedrijfskunde en hrm \\
\hline 11 & hbo economie & hbo recht \\
\hline 12 & hbo economie & hbo hotel, vrijetijd en facility management \\
\hline 13 & hbo techniek & hbo informatica \\
\hline 14 & hbo techniek & hbo werktuigbouwkunde \\
\hline 15 & hbo techniek & hbo elektrotechniek \\
\hline 16 & hbo techniek & hbo chemie \\
\hline 17 & hbo techniek & hbo bouwkunde en civiele techniek \\
\hline 18 & hbo techniek & hbo transport en logistiek \\
\hline 19 & hbo landbouw en natuur & hbo natuur en milieu \\
\hline 20 & hbo landbouw en natuur & hbo landbouw \\
\hline 21 & hbo gezondheidszorg & hbo verpleegkunde en medische diagnostiek \\
\hline 22 & hbo gezondheidszorg & hbo fysiotherapie \\
\hline 23 & hbo gedrag en maatschappij & hbo pedagogiek \\
\hline 24 & hbo gedrag en maatschappij & hbo sociaal cultureel \\
\hline 25 & hbo gedrag en maatschappij & hbo maatschappelijk werk \\
\hline 26 & hbo overig & hbo overig \\
\hline
\end{tabular}

In het wo worden er 7 opleidingscategorieën en 19 -typen onderscheiden:

\begin{tabular}{lll}
1 & wo onderwijs & wo onderwijs \\
\hline 2 & wo taal en cultuur & wo kunst \\
3 & wo taal en cultuur & wo taal, cultuur en journalistiek \\
4 & wo taal en cultuur & wo communicatie \\
5 & wo economie en recht & wo economie \\
6 & wo economie en recht & wo bedrijfseconomie en logistiek \\
7 & wo economie en recht & wo accountancy en financiën \\
8 & wo economie en recht & wo bedrijfskunde en hrm \\
9 & wo economie en recht & wo recht \\
10 & wo techniek & wo informatica \\
11 & wo techniek & wo werktuigbouwkunde en elektrotechniek \\
12 & wo techniek & wo bouwkunde en civiele techniek
\end{tabular}

6 


\begin{tabular}{|lll}
\hline 13 & wo landbouw en natuur & wo biologie, wiskunde, landbouw en milieu \\
\hline 14 & wo landbouw en natuur & wo natuur- en scheikunde \\
\hline 15 & wo medisch & wo (dier)geneeskunde en tandheelkunde \\
16 & wo medisch & wo gezondheidszorg \\
\hline 17 & wo gedrag en maatschappij & wo politicologie en sociologie \\
18 & wo gedrag en maatschappij & wo psychologie en maatschappelijk werk \\
19 & wo overig & wo overig \\
\hline
\end{tabular}

\section{Conclusie en vooruitblik}

In deze notitie is een overzicht gegeven van de opleidingsclassificatie die ROA hanteert bij het maken van de arbeidsmarktprognoses tot 2020 en de actuele cijfers in het ArbeidsmarktInformatieSysteem (AIS). Vanaf 2016 stapt CBS over op ISCED 2011 bij de bepaling van het opleidingsniveau in EBB en op ISCED-F 2013 bij de bepaling van de opleidingsrichting. Als gevolg hiervan zal de opleidingsclassificatie van het ROA vanaf 2016 een combinatie zijn van de CTO (voor niveau) en van de ISCED-F 2013 voor de richting. Deze overgang van ISCED-97 naar ISCED-F 2013 zal mogelijk leiden tot een bijstelling van de hier gepresenteerde opleidingsclassificatie in de nabije toekomst. Het was bij de ontwikkeling van de hier gepresenteerde classificatie niet mogelijk om op deze ontwikkeling vooruit te lopen omdat er nog geen data beschikbaar was. 
Bijlage 1: Onderliggende CTO en ISCED 1997 level codes bij niveau indeling

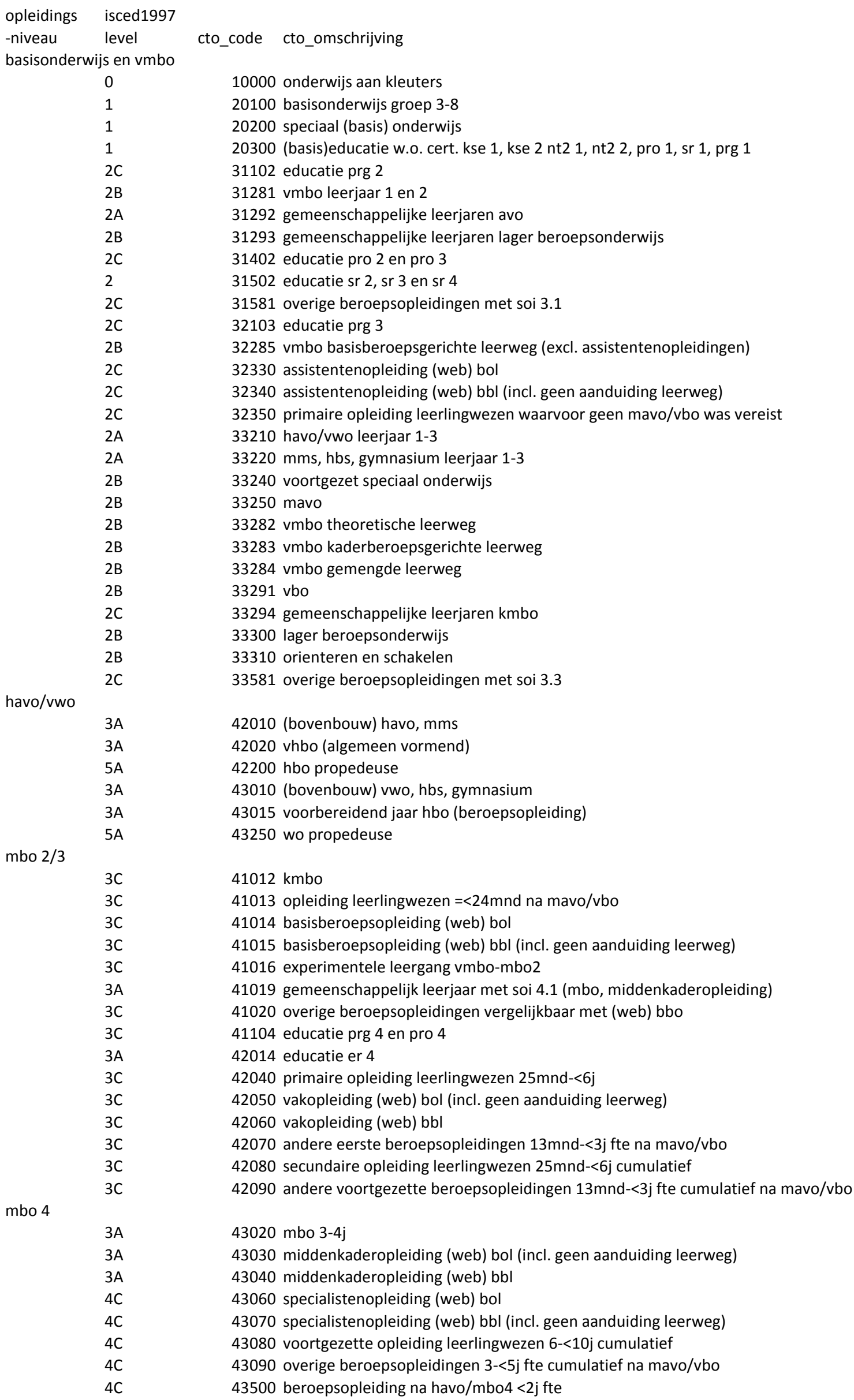

havo/vwo

$3 A$

mbo $2 / 3$

mbo 4

10000 onderwijs aan kleuters

20100 basisonderwijs groep 3-8

20200 speciaal (basis) onderwijs

20300 (basis)educatie w.o. cert. kse 1, kse 2 nt2 1, nt2 2, pro 1, sr 1, prg 1

31102 educatie prg 2

31281 vmbo leerjaar 1 en 2

31292 gemeenschappelijke leerjaren avo

31293 gemeenschappelijke leerjaren lager beroepsonderwijs

31402 educatie pro 2 en pro 3

31502 educatie sr 2 , sr 3 en sr 4

31581 overige beroepsopleidingen met soi 3.1

32103 educatie prg 3

32285 vmbo basisberoepsgerichte leerweg (excl. assistentenopleidingen)

32330 assistentenopleiding (web) bol

32340 assistentenopleiding (web) bbl (incl. geen aanduiding leerweg)

32350 primaire opleiding leerlingwezen waarvoor geen mavo/vbo was vereist

33210 havo/vwo leerjaar 1-3

$33220 \mathrm{mms}$, hbs, gymnasium leerjaar 1-3

33240 voortgezet speciaal onderwijs

33250 mavo

33282 vmbo theoretische leerweg

33283 vmbo kaderberoepsgerichte leerweg

33284 vmbo gemengde leerweg

33291 vbo

33294 gemeenschappelijke leerjaren kmbo

33300 lager beroepsonderwijs

33310 orienteren en schakelen

33581 overige beroepsopleidingen met soi 3.3

42010 (bovenbouw) havo, $\mathrm{mms}$

42020 vhbo (algemeen vormend)

42200 hbo propedeuse

43010 (bovenbouw) vwo, hbs, gymnasium

43015 voorbereidend jaar hbo (beroepsopleiding)

43250 wo propedeuse

41012 kmbo

41013 opleiding leerlingwezen $=<24 \mathrm{mnd}$ na mavo/vbo

41014 basisberoepsopleiding (web) bol

41015 basisberoepsopleiding (web) bbl (incl. geen aanduiding leerweg)

41016 experimentele leergang vmbo-mbo2

41019 gemeenschappelijk leerjaar met soi 4.1 (mbo, middenkaderopleiding)

41020 overige beroepsopleidingen vergelijkbaar met (web) bbo

41104 educatie prg 4 en pro 4

42014 educatie er 4

42040 primaire opleiding leerlingwezen $25 \mathrm{mnd}-<6 \mathrm{j}$

42050 vakopleiding (web) bol (incl. geen aanduiding leerweg)

42060 vakopleiding (web) bbl

42070 andere eerste beroepsopleidingen $13 \mathrm{mnd}-<3 \mathrm{j}$ fte na mavo/vbo

42080 secundaire opleiding leerlingwezen $25 \mathrm{mnd}-<6 \mathrm{j}$ cumulatief

42090 andere voortgezette beroepsopleidingen $13 \mathrm{mnd}-<3$ j fte cumulatief na mavo/vbo

43020 mbo $3-4 j$

43030 middenkaderopleiding (web) bol (incl. geen aanduiding leerweg)

43040 middenkaderopleiding (web) bbl

43060 specialistenopleiding (web) bol

43070 specialistenopleiding (web) bbl (incl. geen aanduiding leerweg)

43080 voortgezette opleiding leerlingwezen $6-<10$ j cumulatief

43090 overige beroepsopleidingen $3-<5$ jte cumulatief na mavo/vbo

43500 beroepsopleiding na havo/mbo $4<2 \mathrm{j}$ fte 


\begin{tabular}{|c|c|c|}
\hline \multirow{3}{*}{$\begin{array}{l}\text { opleidings } \\
\text {-niveau } \\
\text { hbo }\end{array}$} & isced1997 & \multirow[b]{2}{*}{ cto_code cto_omschrijving } \\
\hline & level & \\
\hline & $5 B$ & 51100 kort hbo $2-<3 \mathrm{j} \mathrm{fte}$ \\
\hline & $5 B$ & 51150 hbo associate degree \\
\hline & $5 B$ & 51200 hbo $3-<4$ fte \\
\hline & $5 B$ & 51250 overige beroepsopleidingen na havo/mbo4 2-3j fte \\
\hline & $5 A$ & 52100 tweede- en derdegraadsakten/docentenopleiding \\
\hline & $5 \mathrm{~A}$ & 52115 nascholing tot docent \\
\hline & $5 A$ & 52150 eerstegraadsakte hbo-niveau \\
\hline & $5 A$ & 52210 hbo bachelor (geen docentenopleiding) \\
\hline & $5 A$ & 52250 overige posthbo-opleidingen $<1 \mathrm{j} \mathrm{fte}$ \\
\hline & 5B & 52300 overige beroepsopleidingen na havo/mbo $44-<5$ jte \\
\hline & $5 B$ & 52310 overige beroepsopleidingen met soi 5.2 \\
\hline & $5 \mathrm{~A}$ & 53200 wo bachelor \\
\hline \multicolumn{3}{|r|}{ (5 } \\
\hline & $5 \mathrm{~A}$ & 60100 wo doctoraal 4j dwz 168pnt \\
\hline & $5 \mathrm{~A}$ & 60150 wo master $1 \mathrm{j}$ \\
\hline & $5 A$ & 60155 wo master $2-<3 j$ \\
\hline & $5 A$ & 60200 wo doctoraal 5-6j dwz >168pnt \\
\hline & $5 A$ & 60410 eerstegraadsakte (niet postdoctoraal) \\
\hline & $5 \mathrm{~A}$ & 60420 postdoctorale lerarenopleiding \\
\hline & $5 \mathrm{~A}$ & 60421 educatieve master 1 of 2 jaar (eerstegraadsakte) \\
\hline & $5 A$ & 60450 hbo master \\
\hline & $5 A$ & 60460 tweede fase / posthbo $>=1 \mathrm{j}$ fte $\mathrm{dwz}>=42 \mathrm{pnt}$ \\
\hline & $5 \mathrm{~A}$ & 60510 private mastersopleiding na hbo \\
\hline & $5 \mathrm{~A}$ & 60600 particuliere of bedrijfsopleiding na hbo $>=1 j$ \\
\hline & $5 A$ & 70155 wo master $>=3 j$ \\
\hline & $5 A$ & 70200 wo opleidingen arts en apotheker \\
\hline & $5 \mathrm{~A}$ & 70510 overige tweedefase-opleiding na wo cum $<6 \mathrm{j}$ (excl. lerarenopleiding) \\
\hline & $5 \mathrm{~A}$ & 70520 overige tweedefase-opleiding na wo cum >=6j \\
\hline
\end{tabular}


Bijlage 2: Aantal werkenden naar opleidingsniveau, -categorie en -type en detailed field

opleidings

basisonderwijs en vmbo

basisonderwijs en vmbo

basisonderwijs

0 algemeen

999 onbekend of niet gespecifieerd

10 algemeen

vmbo economie

341 groothandel en detailhandel

811 horeca

340 bedrijfskunde en administratie

346 secretariële en administratieve ondersteuning

342 marketing en public relations

345 management en personeelswetenschappen

344 financieel management en fiscaal recht

812 toerisme en vrijetijdsbesteding

314 economie en econometrie

380 recht

343 financiële dienstverlening

321 journalistiek

322 bibliotheek, documentaire informatievoorziening

320 journalistiek en informatie

vmbo techniek

582 bouwkunde en civiele techniek

521 werktuigbouwkunde en metaalbewerking

522 elektro- en energietechniek

525 voertuigtechniek, scheepsbouw- en vliegtuigbouwkunde

520 techniek en technische dienstverlening

840 transport en logistiek

542 textiel-, kleding-, schoenen-, en leervervaardiging

541 levensmiddelentechnologie

481 informatica

213 audiovisuele techniek en mediaproductie

543 houtbewerking, papier-, kunsttofverwerking, keramiek

523 elektronica en industriële automatisering

524 scheikundige technologie en procestechniek

482 computergebruik

581 architectuur en stedebouwkunde

544 delfstofwinning

vmbo zorg en welzijn

723 verpleging en verzorging

814 huishoudwetenschappen en facilitaire dienstverlening, reiniging

815 schoonheids- en haarverzorging

762 maatschappelijk werk en beroepskeuzewerk

720 gezondheidszorg

813 sport

761 jeugdpedagogisch werk en kinderverzorging

724 tandheelkunde

725 medische diagnostiek en medische technologie

726 therapie en revalidatie

760 sociale dienstverlening

721 geneeskunde

727 farmacie

vmbo groen

621 landbouw en veeteelt

620 landbouw, bosbouw en visserij

622 tuinbouw

640 diergeneeskunde

623 bosbouw

vmbo overig

999 onbekend of niet gespecifieerd

0 algemeen

10 algemeen

861 openbare orde en veiligheid

222 vreemde talen

144 lerarenopleiding basisonderwijs

146 lerarenopleiding beroepsgerichte vakken (incl. muziek, lichamelijke opvoeding)

214 vormgeving

863 krijgsmacht

90 persoonlijke ontplooiing

211 beeldende kunst, kunstgeschiedenis

140 lerarenopleidingen en pedagogisch-didactische cursussen

212 muziek en theater

311 psychologie

143 kleuterleidsters
$1,823,000 \quad 1,776,000$

$465,500 \quad 435,000$

$424,000 \quad 409,000$

$29,500 \quad 26,000$

12,000

$63,000 \quad 61,000$

$23,500 \quad 24,500$

$21,000 \quad 24,500$

$18,500 \quad 16,500$

11,000

10,500

$-$

$-$

$-$

$339,500 \quad 351,500$

$96,000 \quad 102,000$

$65,000 \quad 66,500$

$41,500 \quad 52,500$

$34,000 \quad 37,000$

$25,000 \quad 17,500$

$17,500 \quad 17,000$

10,500

10,500

10,000

-

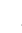

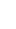

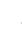

186,500

70,500

60,000

14,500

15,500

166,000

68,000

46,000

14,500

13,000

-

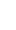

$-$

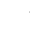

$-$

$47,000 \quad 49,000$

$26,500 \quad 25,000$

$10,000 \quad 12,500$

10,500

$144,000 \quad 147,500$

$49,500 \quad 51,500$

$42,500 \quad 30,000$

$17,500 \quad 26,500$ 
field richting

225 geschiedenis, archeologie, taalwetenschappen

223 moedertaal

312 sociologie en culturele wetenschappen

441 natuurkunde

221 theologie, levensbeschouwing

421 biologie en biochemie

310 sociale en gedragswetenschappen

461 wiskunde

142 onderwijskunde, pedagogiek

852 natuurbehoud, natuurbescherming

210 kunstonderwijs

443 aardwetenschappen

145 lerarenopleiding algemene vakken

850 milieubescherming

80 basiseducatie, alfabetisering

400 wis- en natuurwetenschappen en informatica

215 kunstnijverheid

442 scheikunde

862 veiligheid op het werk en ergonomie

851 milieutechnologie

420 levenswetenschappen

226 filosofie en ethiek

vmbo tl/gl

\section{0 algemeen}

10 algemeen

814 huishoudwetenschappen en facilitaire dienstverlening, reiniging

521 werktuigbouwkunde en metaalbewerking

840 transport en logistiek

541 levensmiddelentechnologie

340 bedrijfskunde en administratie

621 landbouw en veeteelt

522 elektro- en energietechniek

815 schoonheids- en haarverzorging

havo/vwo

havo/vwo

havo/vwo

$$
\begin{array}{r}
0 \text { algemeen } \\
10 \text { algemeen }
\end{array}
$$

481 informatica

840 transport en logistiek

525 voertuigtechniek, scheepsbouw- en vliegtuigbouwkunde

999 onbekend of niet gespecifieerd

380 recht

345 management en personeelswetenschappen

421 biologie en biochemie

210 kunstonderwijs

211 beeldende kunst, kunstgeschiedenis

mbo $2 / 3$

mbo $2 / 3$ groen

mbo $2 / 3$ voedsel, natuur en milieu

621 landbouw en veeteelt

622 tuinbouw

620 landbouw, bosbouw en visserij

640 diergeneeskunde

623 bosbouw

850 milieubescherming

851 milieutechnologie

852 natuurbehoud, natuurbescherming

624 visserij

mbo $2 / 3$ economie

mbo $2 / 3$ commercieel, financieel en administratie

344 financieel management en fiscaal recht

340 bedrijfskunde en administratie

342 marketing en public relations

343 financiële dienstverlening

314 economie en econometrie

341 groothandel en detailhandel

mbo $2 / 3$ detailhandel

mbo $2 / 3$ secretariee

345 management en personeelswetenschappen

346 secretariële en administratieve ondersteuning

mbo 2/3 informatica

481 informatica

482 computergebruik

811 horeca

740,500

740,500

740,500

714,000

26,500

449,500 . 


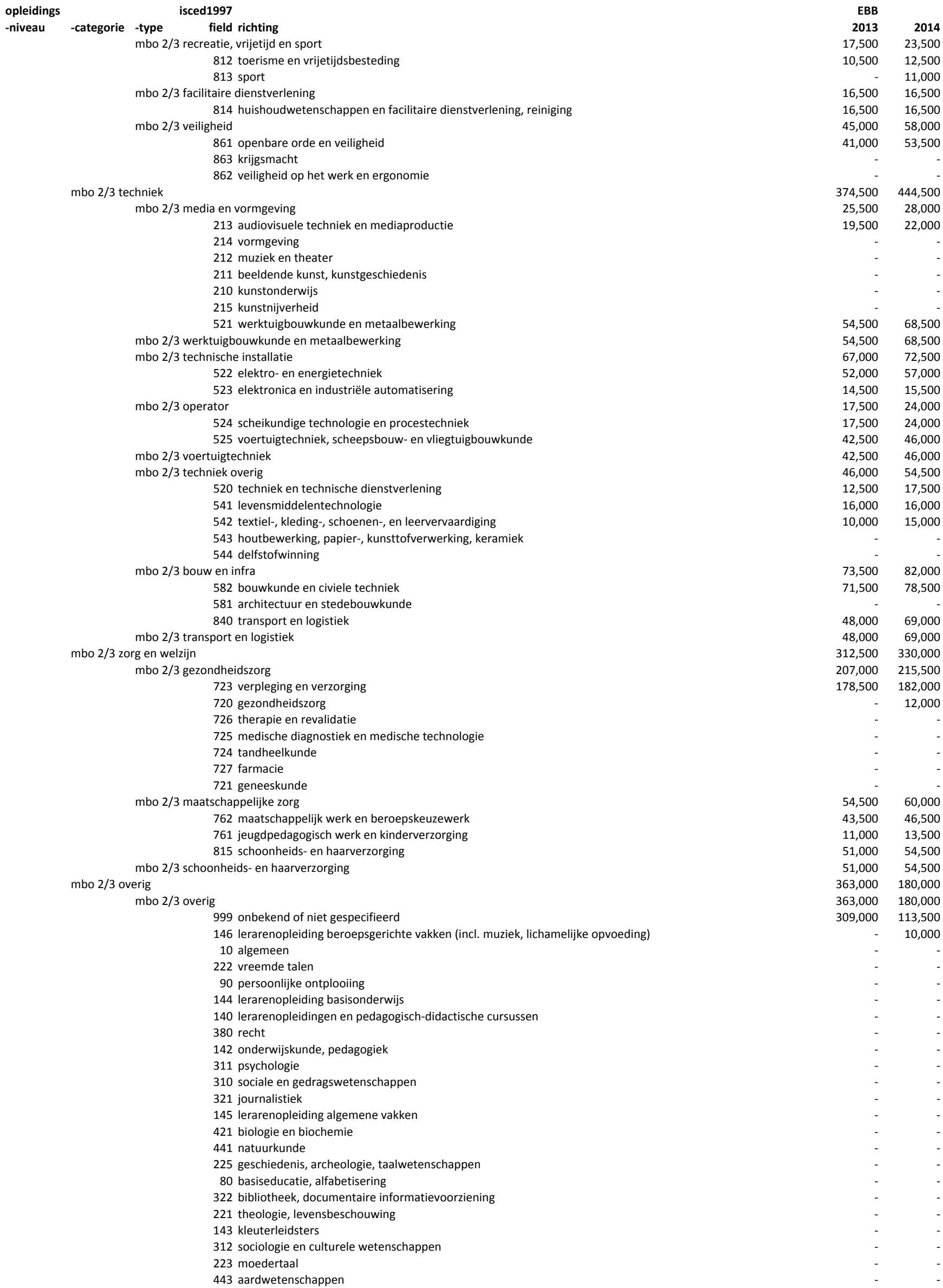




\begin{tabular}{|c|c|c|c|}
\hline \multirow{2}{*}{$\begin{array}{l}\text { opleidings } \\
\text {-niveau }\end{array}$} & \multicolumn{3}{|c|}{ isced1997 } \\
\hline & -categorie & -type & field richting \\
\hline & & & 420 levenswetenschappen \\
\hline & & & 461 wiskunde \\
\hline & & & 313 politicologie en maatschappijwetenschappen \\
\hline & & & 460 wiskunde en statistiek \\
\hline & & & 462 statistiek \\
\hline & & & 226 filosofie en ethiek \\
\hline & & & 400 wis- en natuurwetenschappen en informatica \\
\hline & & & 442 scheikunde \\
\hline & & & 700 gezondheidszorg en welzijn \\
\hline & & & 810 persoonlijke dienstverlening \\
\hline & & & 200 kunst en humaniora \\
\hline
\end{tabular}

mbo 4 mbo 4 groen

mbo 4 voedsel, natuur en milieu

621 landbouw en veeteelt

620 landbouw, bosbouw en visserij

622 tuinbouw

623 bosbouw

640 diergeneeskunde

850 milieubescherming

851 milieutechnologie

mbo 4 economie

mbo 4 commercieel, financieel en administratief

340 bedrijfskunde en administratie

344 financieel management en fiscaal recht

342 marketing en public relations

343 financiële dienstverlening

314 economie en econometrie

341 groothandel en detailhandel

mbo 4 detailhandel

mbo 4 secretarieel

346 secretariële en administratieve ondersteuning

mbo 4 informatica

345 management en personeelswetenschappen

481 informatica

482 computergebruik

811 horeca

mbo 4 horeca

mbo 4 recreatie, vrijetijd en sport

812 toerisme en vrijetijdsbesteding

813 sport

814 huishoudwetenschappen en facilitaire dienstverlening, reiniging

mbo 4 techniek

mbo 4 facilitaire dienstverlening

mbo 4 media en vormgeving

213 audiovisuele techniek en mediaproductie

214 vormgeving

212 muziek en theater

211 beeldende kunst, kunstgeschiedenis

210 kunstonderwijs

215 kunstnijverheid

mbo 4 werktuigbouwkunde en metaalbewerking

521 werktuigbouwkunde en metaalbewerking

mbo 4 technische installatie

522 elektro- en energietechniek

mbo 4 operator

523 elektronica en industriële automatisering

524 scheikundige technologie en procestechniek

525 voertuigtechniek, scheepsbouw- en vliegtuigbouwkunde

mbo 4 voertuigtechniek

mbo 4 techniek overig

542 textiel-, kleding-, schoenen-, en leervervaardiging

520 techniek en technische dienstverlening

541 levensmiddelentechnologie

543 houtbewerking, papier-, kunsttofverwerking, keramiek

544 delfstofwinning

mbo 4 bouw en infra

582 bouwkunde en civiele techniek

581 architectuur en stedebouwkunde

840 transport en logistiek

mbo 4 transport en logistiek

mbo 4 zorg en welzijn

mbo 4 onderwijs

144 lerarenopleiding basisonderwijs

146 lerarenopleiding beroepsgerichte vakken (incl. muziek, lichamelijke opvoeding)

140 lerarenopleidingen en pedagogisch-didactische cursussen
$1,291,000 \quad 1,308,000$

$60,000 \quad 70,000$

$60,000 \quad 70,000$

$32,500 \quad 37,500$

$10,500 \quad 15,000$

$10,500 \quad 11,500$

11,500

-

$484,000 \quad 485,000$

$158,500 \quad 156,500$

$52,000 \quad 50,500$

$44,000 \quad 41,500$

$40,500 \quad 40,500$

$11,000 \quad 13,000$

$11,000 \quad 11,500$

$94,500 \quad 96,000$

$94,500 \quad 96,000$

$117,500 \quad 113,500$

$70,500 \quad 66,000$

$47,500 \quad 47,500$

$27,500 \quad 28,000$

$26,000 \quad 27,000$

$34,000 \quad 35,000$

$34,000 \quad 35,000$

$34,500 \quad 40,500$

$22,000 \quad 26,500$

$13,000 \quad 14,000$

$16,500 \quad 15,000$

$16,500 \quad 15,000$

$369,000 \quad 367,500$

$35,500 \quad 38,000$

$27,500 \quad 30,000$

-

$-$

$66,500 \quad 64,500$

$66,500 \quad 64,500$

$81,000 \quad 81,500$

$53,000 \quad 57,500$

$28,000 \quad 24,000$

$19,000 \quad 19,500$

$19,000 \quad 19,500$

$24,000 \quad 27,000$

$24,000 \quad 27,000$

$53,500 \quad 52,500$

$20,500 \quad 20,000$

$17,500 \quad 17,500$

10,500

$-$

$\begin{array}{ll}60,000 & 58,500 \\ 57,500 & 56,000\end{array}$

-

$29,000 \quad 26,000$

$29,000 \quad 26,000$

$293,000 \quad 298,500$

$29,000 \quad 24,500$

$15,500 \quad 14,000$ 


\begin{tabular}{|c|c|c|c|c|}
\hline \multirow{2}{*}{$\begin{array}{l}\text { opleidings } \\
\text {-niveau }\end{array}$} & \multicolumn{2}{|r|}{ isced1997 } & \multicolumn{2}{|l|}{ EBB } \\
\hline & -categorie & field richting & 2013 & 2014 \\
\hline & & 143 kleuterleidsters & - & - \\
\hline & & 142 onderwijskunde, pedagogiek & - & - \\
\hline & & 145 lerarenopleiding algemene vakken & - & - \\
\hline & & mbo 4 gezondheidszorg & 146,000 & 150,500 \\
\hline & & 723 verpleging en verzorging & 105,000 & 109,000 \\
\hline & & 727 farmacie & 16,000 & 15,500 \\
\hline & & 720 gezondheidszorg & - & - \\
\hline & & 724 tandheelkunde & - & - \\
\hline & & 725 medische diagnostiek en medische technologie & - & - \\
\hline & & 726 therapie en revalidatie & - & - \\
\hline & & 721 geneeskunde & - & - \\
\hline & & mbo 4 maatschappelijke zorg & 94,500 & 97,500 \\
\hline & & 762 maatschappelijk werk en beroepskeuzewerk & 81,500 & 86,000 \\
\hline & & 761 jeugdpedagogisch werk en kinderverzorging & 13,000 & 11,500 \\
\hline & & 760 sociale dienstverlening & - & - \\
\hline & & 815 schoonheids- en haarverzorging & 23,500 & 26,000 \\
\hline & & mbo 4 schoonheids- en haarverzorging & 23,500 & 26,000 \\
\hline & mbo 4 over & & 85,000 & 87,000 \\
\hline & & mbo 4 overig & 85,000 & 87,000 \\
\hline & & 999 onbekend of niet gespecifieerd & 39,000 & 43,000 \\
\hline & & 861 openbare orde en veiligheid & 14,500 & 15,500 \\
\hline & & 380 recht & 10,500 & - \\
\hline & & 10 algemeen & - & - \\
\hline & & 863 krijgsmacht & - & - \\
\hline & & 310 sociale en gedragswetenschappen & - & - \\
\hline & & 420 levenswetenschappen & - & - \\
\hline & & 311 psychologie & - & - \\
\hline & & 322 bibliotheek, documentaire informatievoorziening & - & - \\
\hline & & 421 biologie en biochemie & - & - \\
\hline & & 321 journalistiek & - & - \\
\hline & & 222 vreemde talen & - & - \\
\hline & & 441 natuurkunde & - & - \\
\hline & & 225 geschiedenis, archeologie, taalwetenschappen & - & - \\
\hline & & 312 sociologie en culturele wetenschappen & - & - \\
\hline & & 443 aardwetenschappen & - & - \\
\hline & & 221 theologie, levensbeschouwing & - & - \\
\hline & & 461 wiskunde & - & - \\
\hline & & 400 wis- en natuurwetenschappen en informatica & - & - \\
\hline & & 442 scheikunde & - & - \\
\hline & & 223 moedertaal & - & - \\
\hline & & 90 persoonlijke ontplooiing & - & - \\
\hline & & 80 basiseducatie, alfabetisering & - & - \\
\hline & & 313 politicologie en maatschappijwetenschappen & - & - \\
\hline & & 700 gezondheidszorg en welzijn & - & - \\
\hline & & 862 veiligheid op het werk en ergonomie & - & - \\
\hline hbo & & & $1,746,500$ & $1,766,000$ \\
\hline & hbo onderv & vijs & 227,000 & 224,000 \\
\hline & & hbo leraar basisonderwijs & 145,500 & 141,000 \\
\hline & & 144 lerarenopleiding basisonderwijs & 56,000 & 110,000 \\
\hline & & 140 lerarenopleidingen en pedagogisch-didactische cursussen & 86,000 & 27,500 \\
\hline & & 143 kleuterleidsters & - & - \\
\hline & & 145 lerarenopleiding algemene vakken & 16,000 & 24,000 \\
\hline & & hbo leraar algemene vakken & 16,000 & 24,000 \\
\hline & & hbo leraar beroepsgerichte vakken & 65,500 & 59,000 \\
\hline & & 146 lerarenopleiding beroepsgerichte vakken (incl. muziek, lichamelijke opvoeding) & 65,500 & 59,000 \\
\hline & hbo taal en & 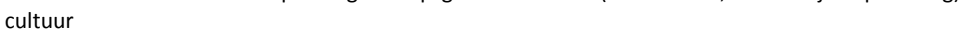 & 133,000 & 133,000 \\
\hline & & hbo kunst & 82,500 & 79,500 \\
\hline & & 213 audiovisuele techniek en mediaproductie & 23,000 & 23,500 \\
\hline & & 212 muziek en theater & 20,000 & 23,000 \\
\hline & & 211 beeldende kunst, kunstgeschiedenis & 22,500 & 20,000 \\
\hline & & 214 vormgeving & 12,500 & 10,000 \\
\hline & & 210 kunstonderwijs & - & - \\
\hline & & 215 kunstnijverheid & - & - \\
\hline & & 310 sociale en gedragswetenschappen & 29,000 & 31,500 \\
\hline & & hbo communicatie & 29,000 & 31,500 \\
\hline & & hbo journalistiek & 21,500 & 22,000 \\
\hline & & 321 journalistiek & 13,500 & 14,500 \\
\hline & & 322 bibliotheek, documentaire informatievoorziening & - & - \\
\hline & hbo econor & nie & 532,500 & 536,000 \\
\hline & & hbo bedrijfseconomie & 93,000 & 95,500 \\
\hline & & 314 economie en econometrie & 52,000 & 52,500 \\
\hline & & 340 bedrijfskunde en administratie & 39,500 & 42,000 \\
\hline & & 313 politicologie en maatschappijwetenschappen & - & - \\
\hline & & hbo marketing en commerciele economie & 90,500 & 92,500 \\
\hline & & 341 groothandel en detailhandel & 58,500 & 58,500 \\
\hline & & 342 marketing en public relations & 32,000 & 34,500 \\
\hline
\end{tabular}




\begin{tabular}{|c|c|c|c|c|}
\hline \multirow{2}{*}{$\begin{array}{l}\text { opleidings } \\
\text {-niveau }\end{array}$} & \multicolumn{2}{|r|}{ isced1997 } & \multicolumn{2}{|l|}{ EBB } \\
\hline & -categorie & -type field richting & 2013 & 2014 \\
\hline & & hbo accountancy en financiën & 55,500 & 55,500 \\
\hline & & 344 financieel management en fiscaal recht & 45,000 & 44,500 \\
\hline & & 343 financiële dienstverlening & 10,000 & 11,000 \\
\hline & & hbo bedrijfskunde en hrm & 180,500 & 179,500 \\
\hline & & 345 management en personeelswetenschappen & 168,000 & 168,000 \\
\hline & & 346 secretariële en administratieve ondersteuning & 12,500 & 11,500 \\
\hline & & 347 arbeidsorganisatie & - & - \\
\hline & & hbo recht & 40,000 & 38,000 \\
\hline & & 380 recht & 25,000 & 24,500 \\
\hline & & 861 openbare orde en veiligheid & 11,000 & 10,500 \\
\hline & & 863 krijgsmacht & - & - \\
\hline & & 862 veiligheid op het werk en ergonomie & - & - \\
\hline & & hbo hotel, vrijetijd en facility management & 73,000 & 75,500 \\
\hline & & 812 toerisme en vrijetijdsbesteding & 29,500 & 30,000 \\
\hline & & 811 horeca & 17,000 & 19,500 \\
\hline & & 814 huishoudwetenschappen en facilitaire dienstverlening, reiniging & 18,500 & 18,000 \\
\hline & & 813 sport & - & - \\
\hline & & 815 schoonheids- en haarverzorging & - & - \\
\hline & hbo techni & & 315,000 & 313,500 \\
\hline & & hbo informatica & 70,500 & 71,500 \\
\hline & & 481 informatica & 69,500 & 71,000 \\
\hline & & 482 computergebruik & - & - \\
\hline & & hbo werktuigbouwkunde & 69,500 & 66,500 \\
\hline & & 521 werktuigbouwkunde en metaalbewerking & 40,500 & 39,500 \\
\hline & & 520 techniek en technische dienstverlening & 15,500 & 14,000 \\
\hline & & 525 voertuigtechniek, scheepsbouw- en vliegtuigbouwkunde & 13,500 & 13,500 \\
\hline & & hbo elektrotechniek & 47,500 & 44,500 \\
\hline & & 522 elektro- en energietechniek & 31,500 & 28,000 \\
\hline & & 523 elektronica en industriële automatisering & 16,000 & 16,500 \\
\hline & & 524 scheikundige technologie en procestechniek & 27,000 & 26,500 \\
\hline & & hbo chemie & 27,000 & 26,500 \\
\hline & & hbo bouwkunde en civiele techniek & 69,500 & 72,000 \\
\hline & & 582 bouwkunde en civiele techniek & 58,500 & 59,000 \\
\hline & & 581 architectuur en stedebouwkunde & 11,000 & 13,000 \\
\hline & & 840 transport en logistiek & 31,500 & 32,500 \\
\hline & & hbo transport en logistiek & 31,500 & 32,500 \\
\hline & hbo landbc & uw en natuur & 64,500 & 67,000 \\
\hline & & hbo natuur en milieu & 42,000 & 44,500 \\
\hline & & 542 textiel-, kleding-, schoenen-, en leervervaardiging & - & - \\
\hline & & 850 milieubescherming & - & - \\
\hline & & 541 levensmiddelentechnologie & - & - \\
\hline & & 421 biologie en biochemie & - & - \\
\hline & & 420 levenswetenschappen & - & - \\
\hline & & 461 wiskunde & - & - \\
\hline & & 441 natuurkunde & - & - \\
\hline & & 443 aardwetenschappen & - & - \\
\hline & & 851 milieutechnologie & - & - \\
\hline & & 543 houtbewerking, papier-, kunsttofverwerking, keramiek & - & - \\
\hline & & 544 delfstofwinning & - & - \\
\hline & & 442 scheikunde & - & - \\
\hline & & 462 statistiek & - & - \\
\hline & & 852 natuurbehoud, natuurbescherming & - & - \\
\hline & & 440 natuurwetenschappen & - & - \\
\hline & & hbo landbouw & 23,000 & 22,500 \\
\hline & & 621 landbouw en veeteelt & 11,500 & - \\
\hline & & 620 landbouw, bosbouw en visserij & - & - \\
\hline & & 623 bosbouw & - & - \\
\hline & & 622 tuinbouw & - & - \\
\hline & & 640 diergeneeskunde & - & - \\
\hline & & 624 visserij & - & - \\
\hline & hbo gezon & dheidszorg & 202,500 & 209,000 \\
\hline & & hbo verpleegkunde en medische diagnostiek & 139,000 & 136,000 \\
\hline & & 723 verpleging en verzorging & 86,000 & 85,000 \\
\hline & & 725 medische diagnostiek en medische technologie & 17,500 & 18,500 \\
\hline & & 721 geneeskunde & 15,000 & 14,500 \\
\hline & & 720 gezondheidszorg & 15,500 & 12,000 \\
\hline & & 724 tandheelkunde & - & - \\
\hline & & 727 farmacie & - & - \\
\hline & & 726 therapie en revalidatie & 63,500 & 73,000 \\
\hline & & hbo fysiotherapie & 63,500 & 73,000 \\
\hline & hbo gedrą & en maatschappij & 214,500 & 223,000 \\
\hline & & 142 onderwijskunde, pedagogiek & 29,500 & 30,500 \\
\hline & & hbo pedagogiek & 29,500 & 30,500 \\
\hline & & hbo sociaal cultureel & 65,000 & 65,000 \\
\hline & & 311 psychologie & 17,500 & 18,000 \\
\hline & & 222 vreemde talen & 14,500 & 15,500 \\
\hline
\end{tabular}




\begin{tabular}{|c|c|c|c|c|}
\hline \multirow{2}{*}{$\begin{array}{l}\text { opleiding } \\
\text {-niveau }\end{array}$} & \multicolumn{2}{|r|}{ isced1997 } & \multicolumn{2}{|l|}{ EBB } \\
\hline & -categorie - & field richting & 2013 & 2014 \\
\hline & & 225 geschiedenis, archeologie, taalwetenschappen & 11,500 & 13,000 \\
\hline & & 312 sociologie en culturele wetenschappen & - & - \\
\hline & & 221 theologie, levensbeschouwing & - & - \\
\hline & & 223 moedertaal & - & - \\
\hline & & 226 filosofie en ethiek & - & - \\
\hline & & 220 humaniora & - & - \\
\hline & & hbo maatschappelijk werk & 120,000 & 128,000 \\
\hline & & 762 maatschappelijk werk en beroepskeuzewerk & 113,000 & 121,500 \\
\hline & & 761 jeugdpedagogisch werk en kinderverzorging & - & - \\
\hline & & 760 sociale dienstverlening & - & - \\
\hline & hbo overig & & 57,000 & 60,500 \\
\hline & & hbo overig & 57,000 & 60,500 \\
\hline & & 999 onbekend of niet gespecifieerd & 49,000 & 51,000 \\
\hline & & 10 algemeen & - & - \\
\hline & & 90 persoonlijke ontplooiing & - & - \\
\hline & & 400 wis- en natuurwetenschappen en informatica & - & - \\
\hline & & 80 basiseducatie, alfabetisering & - & - \\
\hline & & 700 gezondheidszorg en welzijn & - & - \\
\hline & & 200 kunst en humaniora & - & - \\
\hline wo & & & $1,061,500$ & $1,103,000$ \\
\hline & wo onderwijs & & 68,000 & 63,500 \\
\hline & & wo onderwijs & 68,000 & 63,500 \\
\hline & & 142 onderwijskunde, pedagogiek & 33,000 & 29,500 \\
\hline & & 140 lerarenopleidingen en pedagogisch-didactische cursussen & 13,500 & 14,500 \\
\hline & & 146 lerarenopleiding beroepsgerichte vakken (incl. muziek, lichamelijke opvoeding) & 12,000 & 10,000 \\
\hline & & 145 lerarenopleiding algemene vakken & - & - \\
\hline & & 144 lerarenopleiding basisonderwijs & - & - \\
\hline & & 143 kleuterleidsters & - & - \\
\hline & wo taal en cu & cultuur & 141,500 & 151,500 \\
\hline & & wo kunst & 26,000 & 27,000 \\
\hline & & 211 beeldende kunst, kunstgeschiedenis & - & - \\
\hline & & 214 vormgeving & - & - \\
\hline & & 212 muziek en theater & - & - \\
\hline & & 213 audiovisuele techniek en mediaproductie & - & - \\
\hline & & 210 kunstonderwijs & - & - \\
\hline & & 215 kunstnijverheid & - & - \\
\hline & & wo taal, cultuur en journalistiek & 89,000 & 98,500 \\
\hline & & 225 geschiedenis, archeologie, taalwetenschappen & 37,000 & 38,500 \\
\hline & & 222 vreemde talen & 22,000 & 28,500 \\
\hline & & 221 theologie, levensbeschouwing & 10,500 & 14,000 \\
\hline & & 223 moedertaal & - & - \\
\hline & & 226 filosofie en ethiek & - & - \\
\hline & & 321 journalistiek & - & - \\
\hline & & 322 bibliotheek, documentaire informatievoorziening & - & - \\
\hline & & wo communicatie & 26,500 & 26,000 \\
\hline & & 310 sociale en gedragswetenschappen & 26,500 & 26,000 \\
\hline & wo economie & ie en recht & 356,000 & 378,500 \\
\hline & & wo economie & 61,000 & 65,500 \\
\hline & & 314 economie en econometrie & 59,000 & 64,000 \\
\hline & & 811 horeca & - & \\
\hline & & wo bedrijfseconomie en logistiek & 42,500 & 46,000 \\
\hline & & 340 bedrijfskunde en administratie & 16,000 & 16,000 \\
\hline & & 342 marketing en public relations & 10,500 & 14,500 \\
\hline & & 341 groothandel en detailhandel & - & - \\
\hline & & 840 transport en logistiek & - & - \\
\hline & & wo accountancy en financiën & 43,500 & 47,000 \\
\hline & & 344 financieel management en fiscaal recht & 38,500 & 41,000 \\
\hline & & 343 financiële dienstverlening & - & - \\
\hline & & wo bedrijfskunde en hrm & 124,500 & 131,000 \\
\hline & & 345 management en personeelswetenschappen & 120,000 & 128,000 \\
\hline & & 346 secretariële en administratieve ondersteuning & - & - \\
\hline & & 347 arbeidsorganisatie & - & - \\
\hline & & wo recht & 84,000 & 89,000 \\
\hline & & 380 recht & 80,000 & 84,500 \\
\hline & & 861 openbare orde en veiligheid & - & - \\
\hline & & 863 krijgsmacht & - & - \\
\hline & & 862 veiligheid op het werk en ergonomie & - & - \\
\hline & wo techniek & & 130,500 & 145,500 \\
\hline & & wo informatica & 34,000 & 38,500 \\
\hline & & 481 informatica & 34,000 & 38,000 \\
\hline & & 482 computergebruik & - & 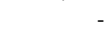 \\
\hline & & wo werktuigbouwkunde en elektrotechniek & 56,500 & 64,500 \\
\hline & & 524 scheikundige technologie en procestechniek & 14,500 & 16,500 \\
\hline & & 521 werktuigbouwkunde en metaalbewerking & 14,000 & 15,500 \\
\hline & & 522 elektro- en energietechniek & 10,000 & 13,000 \\
\hline & & 520 techniek en technische dienstverlening & 10,500 & 11,000 \\
\hline
\end{tabular}




\begin{tabular}{|c|c|c|c|c|}
\hline \multirow{2}{*}{$\begin{array}{l}\text { opleidings } \\
\text {-niveau }\end{array}$} & \multicolumn{2}{|r|}{ isced1997 } & \multicolumn{2}{|l|}{ EBB } \\
\hline & -categorie & field richting & 2013 & 2014 \\
\hline & & 525 voertuigtechniek, scheepsbouw- en vliegtuigbouwkunde & - & - \\
\hline & & 523 elektronica en industriële automatisering & - & - \\
\hline & & wo bouwkunde en civiele techniek & 40,000 & 43,000 \\
\hline & & 582 bouwkunde en civiele techniek & 27,000 & 27,000 \\
\hline & & 581 architectuur en stedebouwkunde & 12,500 & 16,000 \\
\hline & wo landbou & Iw en natuur & 76,000 & 74,500 \\
\hline & & wo biologie, wiskunde, landbouw en milieu & 50,500 & 51,500 \\
\hline & & 421 biologie en biochemie & 15,500 & 18,500 \\
\hline & & 461 wiskunde & - & - \\
\hline & & 621 landbouw en veeteelt & - & - \\
\hline & & 850 milieubescherming & - & - \\
\hline & & 620 landbouw, bosbouw en visserij & - & - \\
\hline & & 623 bosbouw & - & - \\
\hline & & 541 levensmiddelentechnologie & - & - \\
\hline & & 544 delfstofwinning & - & - \\
\hline & & 462 statistiek & - & - \\
\hline & & 542 textiel-, kleding-, schoenen-, en leervervaardiging & - & - \\
\hline & & 851 milieutechnologie & - & - \\
\hline & & 622 tuinbouw & - & - \\
\hline & & 624 visserij & - & - \\
\hline & & 420 levenswetenschappen & - & - \\
\hline & & 852 natuurbehoud, natuurbescherming & - & - \\
\hline & & 543 houtbewerking, papier-, kunsttofverwerking, keramiek & - & - \\
\hline & & 422 milieuwetenschappen & - & - \\
\hline & & wo natuur- en scheikunde & 25,500 & 23,500 \\
\hline & & 441 natuurkunde & 11,000 & 11,500 \\
\hline & & 442 scheikunde & - & - \\
\hline & & 443 aardwetenschappen & - & - \\
\hline & & 440 natuurwetenschappen & - & - \\
\hline & wo medisch & & 147,000 & 145,500 \\
\hline & & wo (dier)geneeskunde en tandheelkunde & 84,000 & 83,000 \\
\hline & & 721 geneeskunde & 69,500 & 69,500 \\
\hline & & 724 tandheelkunde & - & - \\
\hline & & 640 diergeneeskunde & - & - \\
\hline & & wo gezondheidszorg & 63,500 & 62,500 \\
\hline & & 720 gezondheidszorg & 22,500 & 23,500 \\
\hline & & 723 verpleging en verzorging & 14,000 & 15,000 \\
\hline & & 725 medische diagnostiek en medische technologie & 14,500 & 12,500 \\
\hline & & 727 farmacie & - & - \\
\hline & & 726 therapie en revalidatie & - & - \\
\hline & wo gedrag e & en maatschappij & 112,500 & 116,000 \\
\hline & & wo politicologie en sociologie & 48,500 & 50,000 \\
\hline & & 312 sociologie en culturele wetenschappen & 33,500 & 35,000 \\
\hline & & 313 politicologie en maatschappijwetenschappen & - & - \\
\hline & & 812 toerisme en vrijetijdsbesteding & - & - \\
\hline & & 814 huishoudwetenschappen en facilitaire dienstverlening, reiniging & - & - \\
\hline & & 813 sport & - & - \\
\hline & & 815 schoonheids- en haarverzorging & - & - \\
\hline & & wo psychologie en maatschappelijk werk & 64,000 & 66,000 \\
\hline & & 311 psychologie & 53,500 & 58,000 \\
\hline & & 762 maatschappelijk werk en beroepskeuzewerk & - & - \\
\hline & & 761 jeugdpedagogisch werk en kinderverzorging & - & - \\
\hline & wo overig & & 30,000 & 27,000 \\
\hline & & wo overig & 30,000 & 27,000 \\
\hline & & 999 onbekend of niet gespecifieerd & 23,000 & 21,500 \\
\hline & & 400 wis- en natuurwetenschappen en informatica & - & - \\
\hline & & 90 persoonlijke ontplooiing & - & - \\
\hline & & 10 algemeen & - & - \\
\hline & & 80 basiseducatie, alfabetisering & - & - \\
\hline & & 700 gezondheidszorg en welzijn & - & - \\
\hline & & 200 kunst en humaniora & - & - \\
\hline
\end{tabular}


opleidings isced1997

-niveau -categorie -type

overig

overig field richting

999 onbekend of niet gespecifieerd

$\begin{array}{rr}\text { EBB } & \\ \mathbf{2 0 1 3} & \mathbf{2 0 1 4} \\ 141,500 & 81,000 \\ 141,500 & 81,000 \\ 141,500 & 81,000 \\ 141,500 & 81,000\end{array}$


opleidings isce

-type field richting crebo croh crebo croho naam

mbo $2 / 3$ voedsel, natuur en milieu

620 landbouw, bosbouw en visserij

97670 Teelt 2/3 (Vakbekwaam medewerker teelt)

97660 Teelt 2/3 (Medewerker teelt)

97552 Zorg, natuur en gezondheid (Werkbegeleider zorgbedrijf plant)

97110 Binnenteelt (Vakbekwaam medewerker binnenteelt)

621 landbouw en veeteelt
97330 Medewerker dierverzorging

97330 Medewerker dierverzorging

97720 Recreatiedieren (Dierverzorger recreatiedieren)

97703 Productiedieren (Dierverzorger melkvee)

97150 Groen, grond, infra (Vakbekwaam medewerker gemechaniseerd loonbedrijf)

97364 Dierverzorging 3/4 (Dierverzorger recreatiedieren)

97551 Zorg, natuur en gezondheid (Werkbegeleider zorgbedrijf dier)

97510 Hoefsmid

97702 Productiedieren (Dierverzorger hokdieren)

97702 Productiedieren (Dierverzorger hokdieren)

97120 Biologisch-dynamisch bedrijf (Medewerker

97363 Dierverzor

97220 Paardensport (Begeleider paardensport II)

97130 Biologisch-dynamisch bedrijf (Vakbekwaam medewerker biologisch-dynamisch bedrijf)

97701 Productiedieren (Dierverzorger graasdieren)

97770 Proefdieren (Proefdierverzorger)

622 tuinbouw

97570 Rundveepedicure

EBB 2014 DUO 2013

$53.000 \quad 3.720$

$10.000 \quad 280$

140

0

760

760
510

280

190

100

30

30

10

10

10

97531 Natuur en groene ruimte 2 (Medewerker buitenruimte)

97253 Natuur en groene ruimte 3 (Vakbekwaam hovenier)

623 bosbouw

97252 Natuur en groene ruimte 3 (Vakbekwaam medewerker groenvoorziening)

624 visserij

97251 Vakbekwaam medewerker natuur en leefomgeving (Vakbekwaam medewerker bos en natuurbeheer)

640 diergeneeskunde

850 milieubescherming

851 milieutechnologie

97254 Natuur en groene ruimte 3 (Vakbekwaam medewerker land, water en milieu)

852 natuurbehoud, natuurbeschermin

mbo $2 / 3$ commerciel, financieel en administratie

314 economie en econometrie

340 bedrijfskunde en administratie

342 marketing en public relations

90112 Commercieel medewerker (Commercieel medewerker binnendienst)

90111 Commercieel medewerker (Commercieel medewerker binnendienst)

90114 Commercieel medewerker (Contactcenter medewerker)

90113 Commercieel medewerker (Commercieel medewerker buitendienst)

10044 Commercieel Medewerker Binnendienst

343 financiële dienstverlening

344 financieel management en fiscaal recht

93200 Financiële beroepen (Financieel administratief medewerker)

90471 Administratief medewerker (Bedrijfsadministratief medewerker)

mbo $2 / 3$ detailhande 10045 Bedrifsadministratief Medewerker

341 groothandel en detailhandel

93751 Verkoper (Verkoper detailhandel)

90383 Verkoopspecialist (Verkoopspecialist detailhandel)

90384 Verkoopspecialist (Eerste verkoper)

97420 Bloemendetailhandel (Medewerker bloembinden)

97430 Bloemendetailhandel (Vakbekwaam medewerker bloembinden)

97740 Logistiek vakman (Medewerker vershandel, logistiek en transport)

97793 Medewerker groene detailhandel

91652 Medewerker versdetailhandel (Verkoopmedewerker versspeciaalzaak)

97480 Natuur en vormgeving (Vakbekwaam medewerker natuur en vormgeving)

90385 Verkoopspecialist (Verkoopspecialist mode)

97750 Logistiek vakman (Vakbekwaam medewerker vershandel, logistiek en transport)

91653 Medewerker versdetailhandel (Verkoopmedewerker vers supermarkt)

91633 Vakbekwaam medewerker versdetailhandel (Winkelslager)

95600 Leidinggevende vers (Chef vers)

94760 Leidinggevende versindustrie (Meewerkend voorman versindustrie)

95450 Verkoopadviseur Mobiliteitsbranche

90381 Verkoopspecialist (Verkoopadviseur wonen)

97794 Vakbekwaam medewerker groene detailhand

97791 Vakbekwaam verkoper gezelschapsdieren

94740 Leidinggevende versdetailhandel (Chef versdetailhandel)

95332 Logistiek vakman (Logistiek medewerker versindustrie)

97310 Groene detailhandel (Vakbekwaam medewerker groene detailhandel)

92810 Juweliersbedrijf (Medewerker Juwelier)

97410 Gezelschapsdierenbranche (Vakbekwaam verkoper gezelschapsdieren)

91634 Vakbekwaam medewerker versdetailhandel (Visspecialist)

91630 Vakbekwaam medewerker versdetailhandel

97170 Vershandel, logistiek en transport (Vakbekwaam medewerker vershandel, logistiek en transport)

97160 Vershandel, logistiek en transport (Vakbekwaam medewerker vershandel, logistier

90883 Verkoop Mobiliteitsbranche (Verkoopadviseur personenauto's)

91650 Medewerker versdetailhandel

93750 Verkoper

90380 Verkoopspecialist

91640 Chef slagerij

mbo $2 / 3$ secretariee

345 management en personeelswetenschappen

346 secretariële en administratieve ondersteunin

90472 Administratief medewerker (Secretarieel medewerker)

90472 Administratief medewerker (Secreta

95380 Secretariële beroepen (Secretaresse)

90622 Frontofficemedewerker (Receptionist)

93233 Secretariële beroepen (Secretaresse)

90621 Frontofficemedewerker (Informatiemedewerker)

93232 Secretariële beroepen (Medisch secretaresse)

93231 Secretariële beroepen (Juridisch secretaresse)

10046 Secretaresse

93.500

27.000

$15.500 \quad 1.500$

1.010

290
170

10.000

$34.500 \quad 3.080$

3.080
1.760

1.320

$89.000 \quad 9.270$

$\begin{array}{ll}89.000 & 9.270 \\ 89.000 & 9.270\end{array}$

3.830

3.050

940
250

190

150 
90230 Medewerker beheer ICT

90360 Medewerker ICT

482 computergebruik

10904 Medewerker beheer ICT

811 horeca

90760 Kok

95420 Kok (Zelfstandig werkend kok)

94140 Medewerker bediening/café-bar (Gastheer/-vrouw)

94190 Fastservice (Medewerker fastservice)

94153 Medewerker bediening/café-bar (Zelfstandig werkend gastheer/-vrouw)

94200 Fastservice (1e Medewerker fastservice)

94952 Kok (Zelfstandig werkend kok)

90772 Kok (Zelfstandig werkend kok)

94151 Medewerker bediening/café-bar (Bartender)

94152 Medewerker bediening/café-bar (Zelfstandig werkend gastheer/-vrouw) 10395 Zelfstandig Werkend Ko

mbo 2/3 recreatie, vrijetijd en sport

812 toerisme en vrijetijdsbesteding

94110 Leisure \& hospitality (Leisure \& hospitality assistant)

94120 Leisure \& hospitality (Leisure \& hospitality host)

94090 Reizen (Verkoper reizen)

97532 Natuur en groene ruimte 2 (Medewerker recreatiebedrijf)

97532 Natuur en groene ruimte 2 (Medewerker recreatiebedrijf)

97255 Natuur en groene ruimte 3 (Vakbekwaam medewerker recreatiebe

93370 Watersportindustrie (Allround medewerker watersportin

813 spor

10393 Zelfstandig Werkend Medewerker Reizen

95300 Sport- en bewegingsbegeleider

95280 Sport en bewegen (Sport- en bewegingsleider)

91390 Sport en bewegen (Sport- en bewegingsleider)

91380 Sport- en bewegingsbegeleider

97230 Paardensport (Instructeur paardensport III)

mbo $2 / 3$ facilitaire dienstverlening

10873 Sport-en Bewegingsleider

814 huishoudwetenschappen en facilitaire dienstverlening, reiniging

95751 Facilitair medewerker

94170 Facilitaire dienstverlener (Facilitaire medewerker)

94541 Schoonmaak en glazenwassen (Allround schoonmaker/medewerker vloeronderhoud)

94531 Schoonmaak en glazenwassen (Schoonmaker/medewerker vloeronderhoud)

94534 Schoonmaak en glazenwassen (Reiniger in de voedselverwerkende industrie)

mbo $2 / 3$ veiligheid

861 openbare orde en veiligheid

94850 Particuliere beveiliging (Beveiliger)

94810 Toezicht en veiligheid (Handhaver toezicht en veiligheid)

93280 Toezicht en veiligheid (Medewerker toezicht en veiligheid)

90550 Particuliere beveiliging (Coördinator beveiliging)

90541 Particuliere beveiliging (Beveiliger)

10876 Beveiliger

10910 Coördinator beveiliging

862 veiligheid op het werk en ergonomie

863 krijgsmacht

95081 Veiligheid en vakmanschap (Aankomend medewerker grondoptreden)

95091 Veiligheid en vakmanschap (Aankomend onderofficier grondoptreden)

95082 Veiligheid en vakmanschap (Aankomend medewerker maritiem)

95090 Veiligheid en vakmanschap

mbo 2/3 media en vormgeving

95092 Veiligheid en vakmanschap (Aankomend onderofficier maritiem)

210 kunstonderwijs

211 beeldende kunst, kunstgeschiedenis

212 muziek en theater

213 audiovisuele techniek en mediaproductie

90191 DTP-er (Allround DTP-er)

94500 Signmaker (Medewerker sign)

95707 Medewerker DTP

90061 AV-productie (Allround medewerker AV-productie)

90330 Podium- en evenemententechniek (Podium- en evenemententechnicus)

95705 Allround DTP-er

95712 medewerker Podium- en evenemententechniek

94510 Signmaker (Allround signmaker)

95717 Basismedewerker printmedia

95708 Medewerker DTP

90192 DTP-er (Allround DTP-er Savantis)

95706 Allround DTP-er

90181 DTP-er (Medewerker DTP)

90053 AV-productie (Medewerker Fotografie)

95713 Podium- en evenemententechnicus

90052 AV-productie (Medewerker Fotografie)

90320 Podium- en evenemententechniek (Medewerker Podium- en evenemententechniek)

90051 AV-productie (Medewerker Fotografie)

95719 Drukker

90063 AV-productie (Allround medewerker AV-productie)

95718 Digitaal Drukker

90182 DTP-er (Medewerker DTP)

90060 AV-productie

92227 Printmedia (Zeefdrukken)

95720 Nabewerker

92222 Printmedia (Geniet brocheren)

214 vormgeving

92225 Printmedia (Vellenoffset)

215 kunstnijverheid

91530 Vormgeving ruimtelijke presentatie en communicatie (Medewerker productpresentatie) 


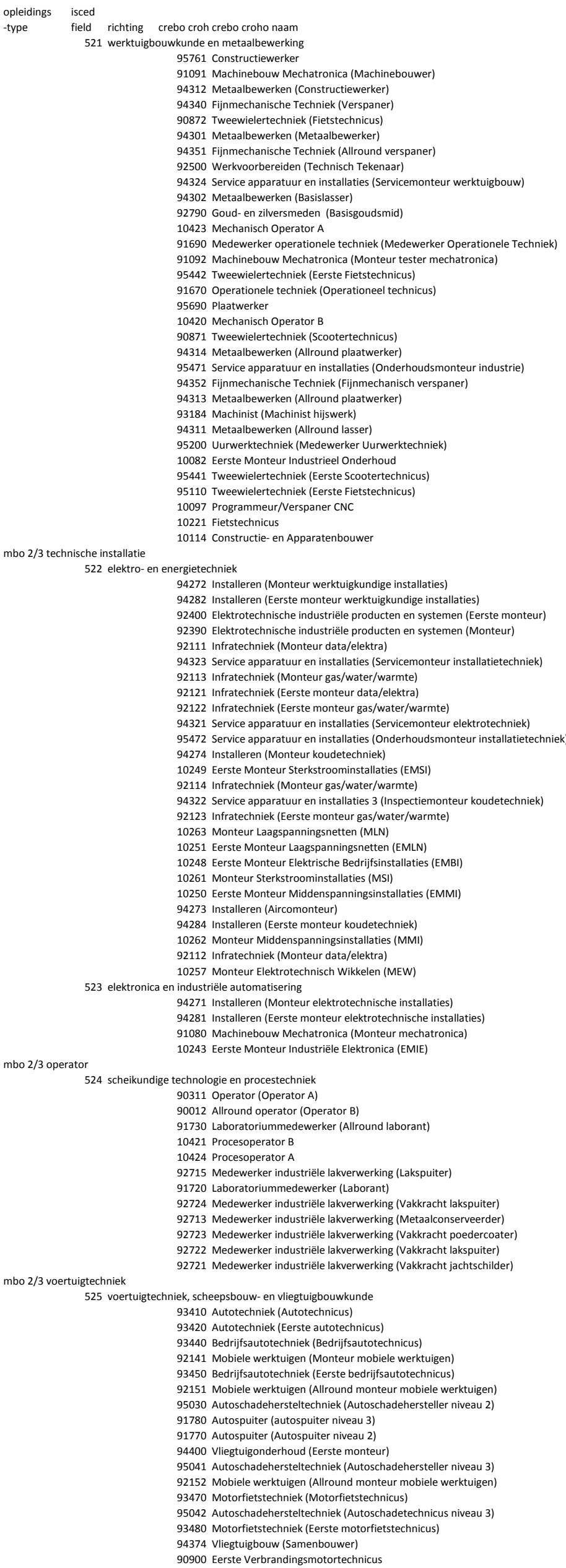


10206 Eerste Autotechnicus

91790 Carrosseriebouwer (Carrosseriebouwer niveau 2)

91800 Carrosseriebouwer (Carrosseriebouwer niveau 3)

10205 Eerste Bedrijfsautotechnicus

93390 Serviceadviseur Mobiliteitsbranche

95492 Vliegtuigtechniek (Plaat-/kunststofbewerker)

95762 Eerste monteur

92230 Assemblagetechnicus Mobiliteitsbranche (Assemblagetechnicus Mobiliteitsbranche)

10222 Bedrijfsautotechnicus

10223 Autotechnicus

93141 Verbrandingsmotortechniek (Revisietechnicus verbrandingsmotoren)

92142 Mobiele werktuigen (Monteur mobiele werktuigen)

mbo $2 / 3$ techniek overis

10200 Eerste Autoschadehersteller

520 techniek en technische dienstverlening

90312 Operator (Operator productietechniek)

90011 Allround operator (Allround operator productietechniek)

541 levensmiddelentechnologie

95747 Uitvoerend bakke

90313 Operator (Voedingsoperator)

97380 Operator (Voedingsoperator)

97340 Allround operator (Allround voedingsoperator)

91651 Medewerker versdetailhandel (Productiemedewerker versdetailhandel)

94232 Brood en banket (Allround banketbakker)

94233 Brood en banket (Allround brood- en banketbakker)

95748 Zelfstandig werkend banketbakker

94221 Brood en banket (Brood- en banketbakker)

90014 Allround operator (Allround voedingsoperator)

95749 Zelfstandig werkend broodbakker

94222 Brood en banket (Banketbakker)

93700 Productiemedewerker versindustrie

94231 Brood en banket (Allround broodbakker)

91631 Vakbekwaam medewerker versdetailhandel (Slager-traiteur)

10497 All-Round Brood- en Banketbakker

91632 Vakbekwaam medewerker versdetailhandel (Worstmaker)

10496 All-Round Banketbakker

10500 Brood-en Banketbakker

94730 Productievakkracht versindustrie

542 textiel-, kleding-, schoenen-, en leervervaardiging

91240 Medewerker mode/maatkleding (Basismedewerker mode/maatkleding)

91250 Medewerker mode/maatkleding (Allround medewerker mode/maatkleding)

93610 Schoenhersteller

90314 Operator (Operator textiel)

90015 Allround operator (Specialist textiel)

95590 Schoenhersteller (Schoenhersteller/Ondernemer)

543 houtbewerking, papier-, kunsttofverwerking keramiek

95000 Machinaal houtbewerker

95570 Machinaal houtbewerker (Allround machinaal hout)

94610 Montagemedewerker timmerindustrie

94621 Montagemedewerker timmerindustrie (Allround montagemedewerker gevelelementen)

92980 Caravantechnicus (Caravantechnicus niveau 2)

94581 Meubelmaker/(scheeps)interieurbouwer (Allround meubelmaker)

94622 Montagemedewerker timmerindustrie (Allround houtskeletbouwer)

93533 Machinaal houtbewerker (Allround machinaal houtbewerker timmerindustrie)

10930 Allround Machinaal Houtbewerker Meubelindustrie

10929 Allround Meubelmaker

544 delfstofwinning

10933 Meubelmaker

581 architectuur en stedebouwkunde

582 bouwkunde en civiele techniek

94920 Timmerman

94570 Meubelmaker/(scheeps)interieurbouwer

94932 Timmerman (Allround timmerman nieuwbouw)

91450 Medewerker schilderen (Schilder)

93183 Machinist (Machinist grondverzet)

94931 Timmerman (Allround timmerman bouw- en werkplaats)

92180 Onderhoud- en verbouwbedrijf (Servicemedewerker gebouwen)

95580 Meubelmaker/(scheeps)interieurbouwer (Allround meubelmaker/(scheeps)interieurbouwer)

91461 Medewerker schilderen (Gezel schilder aankomend voorman)

93980 Vakman gww

94582 Meubelmaker/(scheeps)interieurbouwer (Allround interieurbouwer)

94000 Straatmaker (Opperman bestratingen)

93901 Metselaar (Metselaar inclusief casco lijmwerk)

93902 Metselaar (Metselaar inclusief lichte scheidingswanden)

93600 Medewerker stukadoren (Stukadoor)

94933 Timmerman (Allround timmerman restauratie)

94040 Betonboorder

93830 Steigerbouwer (Allround steigerbouwer)

95684 Gezel schilder

94823 Metselaar (Allround Metselaar aan - en verbouw)

93990 Vakman gww (Allround vakman gww)

93910 Tegelzetter

93841 Dakdekker (Dakdekker bitumen en kunststof)

94822 Metselaar (Allround Metselaar herstel en restauratie)

93820 Steigerbouwer

95689 Isolatiemonteu

93560 Meubelstoffeerder

93853 Dakdekker (Allround dakdekker bitumen en kunststof)

94010 Straatmake

95272 Onderhoud- en verbouwbedrijf (Allround ondernemer klussenbedriif)

91501 Medewerker stukadoren (Gezel stukadoor decoratie)

93570 Meubelstoffeerder (Allround meubelstoffeerder)

93846 Dakdekker (Dakdekker pannen/leien)

93843 Dakdekker (Dakdekker metaal)

94821 Metselaar (Allround Metselaar inclusief nieuwe metseltechnieken)

93855 Dakdekker (Allround dakdekker pannen/leien)

91510 Tentoonstellingsbouwer (Medewerker tentoonstellingsbouw) 


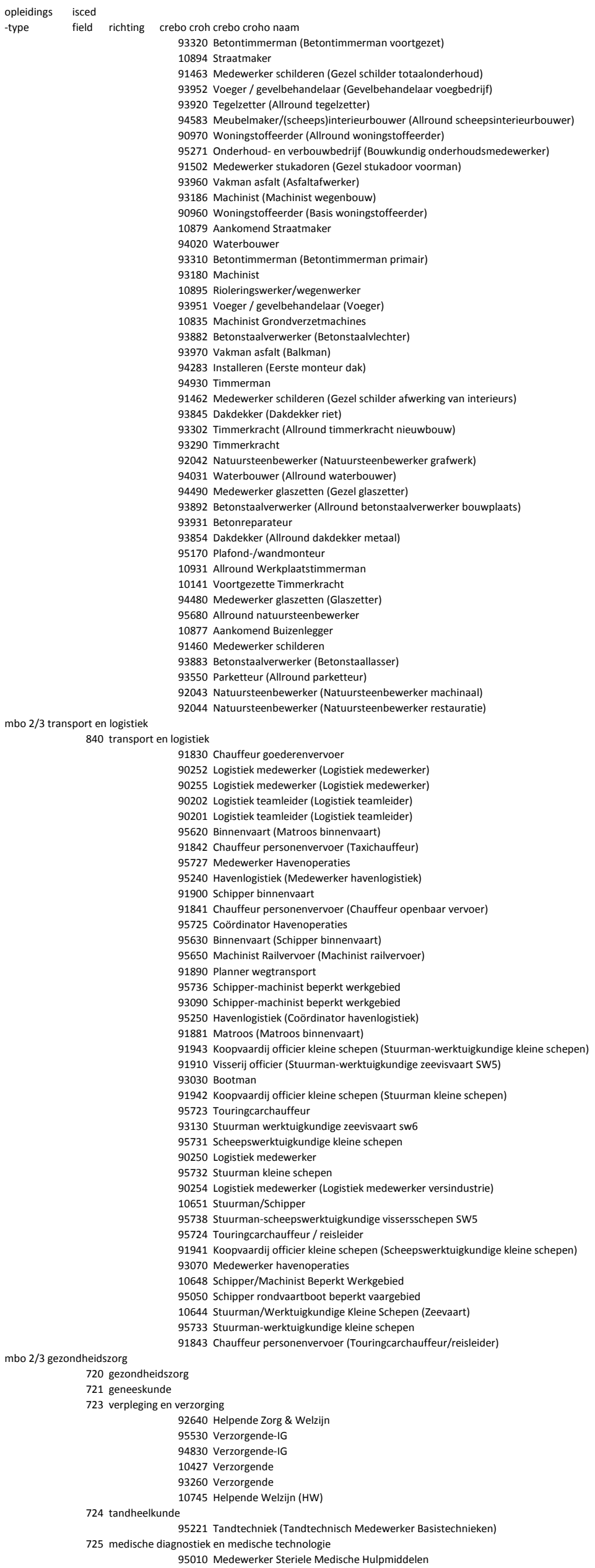


95190 Orthopedisch Technisch Medewerke

93640 Optiek (Allround medewerker Optiek)

94690 Orthopedisch schoentechnisch medewerker (Schoentechnisch voorzieningenmaker)

95697 Orthopedisch Technisch Medewerker

95698 Schoentechnisch Voorzieningenmaker

727 farmacie

mbo 2/3 maatschappelijke zorg

761 jeugdpedagogisch werk en kinderverzorgin

762 maatschappelijk werk en beroepskeuzewerk

92620 Pedagogisch Werk (Pedagogisch medewerker 3 kinderopvang)

92650 Maatschappelijke Zorg (Medewerker maatschappelijke zorg) 10742 Sociaal Pedagogisch Werker 3 (SPW 3)

mbo 2/3 schoonheids- en haarverzorgin

815 schoonheids- en haarverzorging

95120 Kapper (Junior Kapper)

91182 Kapper (Kapper)

95746 Schoonheidsspecialist

91190 Schoonheidsspecialist

95500 Schoonheidsspecialist

95744 Pedicure

10507 All-Round Kapper

94430 Pedicure

91181 Kapper (Afrokapper)

91172 Kapper

10506 Schoonheidsspecialist

180.000

10 algemeen

80 basiseducatie, alfabetiserin

90 persoonlijke ontplooiing

140 lerarenopleidingen en pedagogisch-didactische cursussen

142 onderwijskunde, pedagogiek

143 kleuterleidsters

144 lerarenopleiding basisonderwijs

145 lerarenopleiding algemene vakken

146 lar

46 lerarenopleiding beroepsgerichte vakken (incl. muziek, lichamelijke opvoeding)

manior

221 theologie, levensbeschouwing

222 vreemde talen

223 moedertaal

225 geschiedenis, archeologie, taalwetenschappen

226 filosofie en ethiek

310 sociale en gedragswetenschappen

311 psychologie

312 sociologie en culturele wetenschappen

313 politicologie en maatschappijwetenschappen

321 journalistiek

322 bibliotheek, documentaire informatievoorziening

380 recht

400 wis- en natuurwetenschappen en informatica

420 levenswetenschappen

421 biologie en biochemie

441 natuurkunde

442 scheikunde

443 aardwetenschappen

461 wiskunde

62 statistiek

700 gezondheidszorg en welzij

810 persoonlijke dienstverlenin

999 onbekend of niet gespecifieerd

mbo 4 voedsel, natuur en milieu

620 landbouw, bosbouw en visserij

97681 Teelt 4 (Manager teelt)

97562 Zorg, natuur en gezondheid (Ondernemer zorgbedrijf plant)

97034 Teelt en ondernemerschap (Manager buitenteelt)

97033 Teelt en ondernemerschap (Manager binnenteelt)

621 landbouw en veeteelt

97053 Dierenhouderij (Manager dierverzorging)

97730 Recreatiedieren (Ondernemer/manager recreatiedieren)

97054 Dierenhouderij (Melkveehouder)

93810 Mobiele werktuigen (Technicus landbouwmechanisatie)

97713 Productiedieren (Melkveehouder)

97561 Zorg, natuur en gezondheid (Ondernemer zorgbedrijf dier)

97650 Groen, grond, infra (Manager gemechaniseerd loonbedrijf)

97712 Productiedieren (Dierenhouder hokdieren)

97242 Paardensport (Manager paardensportbedrijf)

97640 Biologisch-dynamisch bedrijf (Manager biologisch-dynamisch bedrijf)

97052 Dierenhouderij (Dierenhouder hokdieren)

97051 Dierenhouderij (Dierenhouder graasdieren)

97711 Productiedieren (Dierenhouder graasdieren)

622 tuinbouw

97090 Manager natuur en recreatie

623 bosbouw

640 diergeneeskunde

97590 Dierenartsassistent paraveterinair

850 milieubescherming

97040 Dierenassistent paraveterinair

97372 Milieu en ruimte (Milieufunctionaris)
97371 Milieu en ruimte (Toezichthouder milieu en ruimte)

851 milieutechnologie

mbo 4 commercieel, financieel en administratie

314 economie en econometrie

340 bedrijfskunde en administratie

342 marketing en public relations

$70.000 \quad 2.240$

15.000

37.500

11.500

0.000 
90500 Commercieel medewerker bank-en verzekeringswezen

341 groothandel en detailhandel

93492 Manager handel (Filiaalmanager)

93492 Manager handel (Filiaalm

93494 Manager handel (Vestigingsmanager groothandel)

93491 Manager handel (Afdelingsmanager)

97490 Natuur en vormgeving (Specialist natuur en vormgeving)

90933 Assistent-manager internatinale handel (Asistent-manager internationale handel binnendienst)

97761 Logistiek vakman (Manager vershandel, logistiek en transport)

97440 Bloemendetailhandel (Manager bloembinden)

97792 Manager groene detailhandel

90850 Verkoopmanager Mobiliteitsbranche

90932 Assistent-manager internationale handel (Assistent-manager internationale handel buitendienst)

90931 Exportmedewerker (Exportmedewerker binnendienst)

97400 Gezelschapsdierenbranche (Ondernemer gezelschapsdieren)

92820 Juweliersbedrijf (Juwelier)

97450 Groene detailhandel (Manager groene detailhandel)

93493 Manager handel (Manager wonen)

93490 Manager handel

94750 Leidinggevende versdetailhandel (Ondernemer versdetailhandel)

97790 Ondernemer gezelschapsdieren

97010 Manager vershandel, logistiek en transport

95610 Leidinggevende vers (Ondernemer vers)

mbo 4 secretariee

10002 Ondernemer Groothandel

345 management en personeelswetenschappen

95391 Secretariële beroepen (Directiesecretaresse/managementassistent)

94072 Frontofficemedewerker (Frontofficemanager)

94892 Juridisch medewerker openbaar bestuur

94900 Medewerker personeel en arbeid

93251 Secretariële beroepen (Directiesecretaresse)

95400 Mediamanagement (Ordermanager creatieve industrie)

93252 Secretariële beroepen (Managementassistent)

92512 Werkvoorbereiden (Werkvoorbereider fabricage)

94071 Frontofficemedewerker (Hoofd informatie)

90601 Mediamanagement (Media intermediair)

90603 Mediamanagement (Mediaproductie management)

10040 Directiesecretaresse / Management Assistent

93250 Secretariële beroepen

90432 Juridisch medewerker (Openbaar bestuur)

346 secretariële en administratieve ondersteuning

95393 Secretarièle beroepen (Medisch secretaresse)

mbo 4 informatica

95392 Secretariële beroepen (Juridisch secretaress

481 informatica

93191 ICT-beheer (ICT-beheerder)

95321 ICT- en mediabeheer (ICT-beheerder)

90020 Applicatieontwikkelaar

93192 ICT-beheer (Netwerkbeheerder)

95311 Applicatie- en mediaontwikkeling (Applicatieontwikkelaa )

95323 ICT- en mediabeheer (Netwerkbeheerder)

95313 Applicatie- en mediaontwikkeling (Mediadeveloper)

90612 Mediatechnologie (Webdeveloper)

95322 ICT- en mediabeheer (Mediaworkflowbeheerder)

90611 Mediatechnologie (Crossmedia publishing)

92200 Particulier digitaal onderzoeker

90613 Mediatechnologie (Workflow beheer)

90222 ICT-beheerder (Servicedesk)

482 computergebru

10908 Netwerkbeheerder

90303 Ondernemer horeca/bakkerij (Manager/ondernemer horeca)

94161 Medewerker bediening/café-bar (Leidinggevende bediening)

90301 Ondernemer horeca/bakkerij (Manager/ondernemer café-bar)

95101 Kok (Gespecialiseerd kok)

95102 Kok (Leidinggevende keuken)

10388 Horeca-ondernemer/-manager

95432 Fastservice (Manager/ bedrijfsleider fastservice)

90302 Ondernemer horeca/bakkerij (Manager/ondernemer fastservice)

94210 Fastservice (Bedrijfsleider fastservice)

94163 Medewerker bediening/café-bar (Gastronoom/sommelier)

10386 Horeca-Ondernemer Café/Bar en Fast Food

93360 Kok (Leidinggevende keuken)

mbo 4 recreatie, vrijetijd en sport

812 toerisme en vrijetijdsbestedin

94130 Leisure \& hospitality (Leisure \& hospitality executive)

90534 Medewerker marketing en communicatie (Medewerker evenementenorganisatie)

94100 Reren (Manas

94980 Watersportindustrie (Werkend voorman watersportindustire)

10384 Middenkaderfunctionaris Reizen

813 sport

91404 Sport en bewegen (Sport- en bewegingscoördinator / Trainer-coach)

91401 Sport en bewegen (Sport- en bewegingscoördinator / Bewegingsagoog)

91403 Sport en bewegen (Sport- en bewegingscoördinator / Operationeel sport- en bewegingsmanager) 
90940 Interieuradviseur

91542 Vormgeving ruimtelijke presentatie en communicatie (Vormgever productpresentatie) 91541 Vormgeving ruimtelijke presentatie en communicatie (Stand-, winkel en decorvormgever) 94524 Middenkaderfunctionaris afbouw en onderhoud (Kleur- en interieuradvies) 91543 Vormgeving ruimtelijke presentatie en communicatie (Winkelpubliciteitvormgever)

215 kunstnijverheid 94790 Human technology 
10528 Servicetechnicus (ST)

10235 Middenkaderfunctionaris Automatiserings Energietechniek (MK-AEN) 523 elektronica en industriële automatisering
10074 Onderhoudstechnicus Instrumentatie

mbo 4 operator

524 scheikundige technologie en procestechniek

93714 Analist (Chemisch-fysisch analist)

90240 Operator C

10419 Procesoperator C

93716 Analist (Technisch onderwijsassistent (TOA))

mbo 4 voertuigtechniek

525 voertuigtechniek, scheepsbouw- en vliegtuigbouwkunde

93430 Autotechniek (Technisch specialist personenauto's)
93384 Werkplaatsmanagement Mobiliteitsbranche (Werkplaatsmanager Motorvoertuigentechniek)

93384 Werkplaatsmanagement Mobiliteitsbranche (Wer

93460 Bedrijfsautotechniek (Technisch specialist bedrijfsauto's)

94251 Bedrijfsmanagement Mobiliteitsbranche (Bedrijfsmanager Mobiliteitsbranche Innovam)

93080 Scheeps-en jachtbouwkundige

93386 Werkplaatsmanagement Mobiliteitsbranche (Werkplaatsmanager Schadeherstel)

93382 Werkplaatsmanagement Mobiliteitsbranche (Werkplaatsmanager motorvoertuigentechniek)

94411 Vliegtuigonderhoud (Technicus avionica)

95722 Technisch Specialist Verbrandingsmotoren

95764 Technicus mechanica

10845 Bedrijfsmanager Carrosseriebouwbedrij

10845 Bedrijfsmanager Carrosseriebouwbedrijf

mbo 4 techniek overig

93401 Bedrijfsmanagement Mobiliteitsbranche (Bedrijfsmanager Mobiliteitsbranche Innovam)

520 techniek en technische dienstverlening

94421 Middenkader engineering (Technicus)

94422 Middenkader engineering (Commercieel technicus)

541 levensmiddelentechnologie

97541 Voedingsmanagement (Voedingsspecialist)

94242 Brood en banket (Leidinggevende ambachtelijke bakkerij)

97542 Voedingsmanagement (Manager voeding)

94241 Brood en banket (Patissier)

97520 Kwaliteitscoördinator

90304 Ondernemer horeca/bakkerij (Ondernemer bakkerij)

10826 Leidinggevende Ambachtelijke Bakkerij

542 textiel-, kleding-, schoenen-, en leervervaardiging

94471 Medewerker design (Medewerker styling)

91260 Medewerker mode/maatkleding (Specialist mode/maatkleding)

93781 Productiecoördinator (Commercieel medewerker fashion)

94460 Commercieel medewerker buitendienst textiel

93685 Creatief vakman (Lederwarenmaker)

93684 Creatief vakman (Hoedenmaker)

94472 Medewerker design (CAD-stylist)

93683 Creatief vakman (Ambachtelijk schoenmaker)

543 houtbewerking, papier-, kunsttofverwerking, keramiek

94592 Meubelmaker/(scheeps)interieurbouwer (Ondernemer meubelindustrie/(scheeps)interieurbouw)

93686 Creatief vakman (Ontwerpend Meubelmaker)

94651 Werkvoorbereider houtbranche (Werkvoorbereider meubelindustrie/(scheeps)interieurbouw)

94591 Meubelmaker/(scheeps)interieurbouwer (Meewerkend leidinggevende meubelindustrie/(scheeps)interieurbouw)

94652 Werkvoorbereider houtbranche (Werkvoorbereider timmerindustrie)

93681 Creatief vakman (Glazenier)

10927 Kaderfuntionaris Meubelindustie en Interieurbouw

94630 Montagemedewerker timmerindustrie (Meewerkend leidinggevende montage timmerindustrie)

94550 Machinaal houtbewerker (Meewerkend leidinggevende machinaal houtbewerken)

544 delfstofwinning 93682 Creatief vakman (Keramist)

581 architectuur en stedebouwkunde

94053 Middenkaderfunctionaris bouw en infra (Middenkaderfunctionaris landmeetkunde)

582 bouwkunde en civiele techniek

94051 Middenkaderfunctionaris bouw en infra (Middenkaderfunctionaris bouw)

93873 Kaderfunctionaris bouw, infra en gespecialiseerde aannemerij (Kaderfunctionaris uitvoering bouw en infra)

94052 Middenkaderfunctionaris bouw en infra (Middenkaderfunctionaris infra)

94052 Middenkaderfunctionaris bouw en infra (Middenkaderfunction

92741 Specialist schilderen (Specialist decoratie en restauratie)

94525 Middenkaderfunctionaris afbouw en onderhoud (Projectleider)

94523 Middenkaderfunctionaris afbouw en onderhoud (Ondernemer)

93872 kaderfunctionaris bouw, infra en gespecialiseerde aannemerij (Kaderfunctionaris uitvoering)

10131 Assistent Uitvoerder Burger en Utiliteitsbouw

94522 Middenkaderfunctionaris afbouw en onderhoud (Uitvoerder)

93871 Kaderfunctionaris bouw, infra en gespecialiseerde aannemerij (Kaderfunctionaris werkvoorbereiding en calculatie)

92742 Specialist schilderen (Specialist interieur en decoratie)

94054 Middenkaderfunctionaris bouw en infra (Middenkaderfunctionaris verkeer en stedenbouw)

94055 Middenkaderfunctionaris bouw en infra (Middenkaderfunctionaris restauratie)

10801 Restauratiemedewerker

93020 Baggermeester

94050 Middenkaderfunctionaris bouw en infr

90262 Middenkaderfunctionaris bouw en infra (Infra)

94602 Meubelstoffeerder (Ondernemer meubelstoffeerbedrijf)

90261 Middenkaderfunctionaris bouw en infra (Bouw)

mbo 4 transport en logistiek

840 transport en logistiek

91850 Luchtvaartdienstverlener

91870 Manager transport en logistiek (manager transport en logistiek)

91870 Manager transport en logistiek (manager transport 90216 Logistiek supervisor (Logistiek supervisor KC Handel)

90216 Logistiek supervisor (Logistiek supervisor KC

90217 Logistiek supervisor (Logistiek supervisor VTL)

91931 Koopvaardij officier alle schepen (Maritien

90213 Logistiek supervisor (Logistiek supervisor)

91933 Koopvaardij officier alle schepen (Stuurman alle schepen)

93010 Aviation operations officer (Aviation operations officer)

EBB 2014 DUO 2013

$\begin{array}{rr} & 10 \\ & \\ 24.000 & 10 \\ & 10 \\ 19.500 & 410 \\ 19.500 & 410 \\ & 230 \\ & 130 \\ & 50 \\ & 10 \\ & 10\end{array}$

27.000

$27.000-1.040$ 


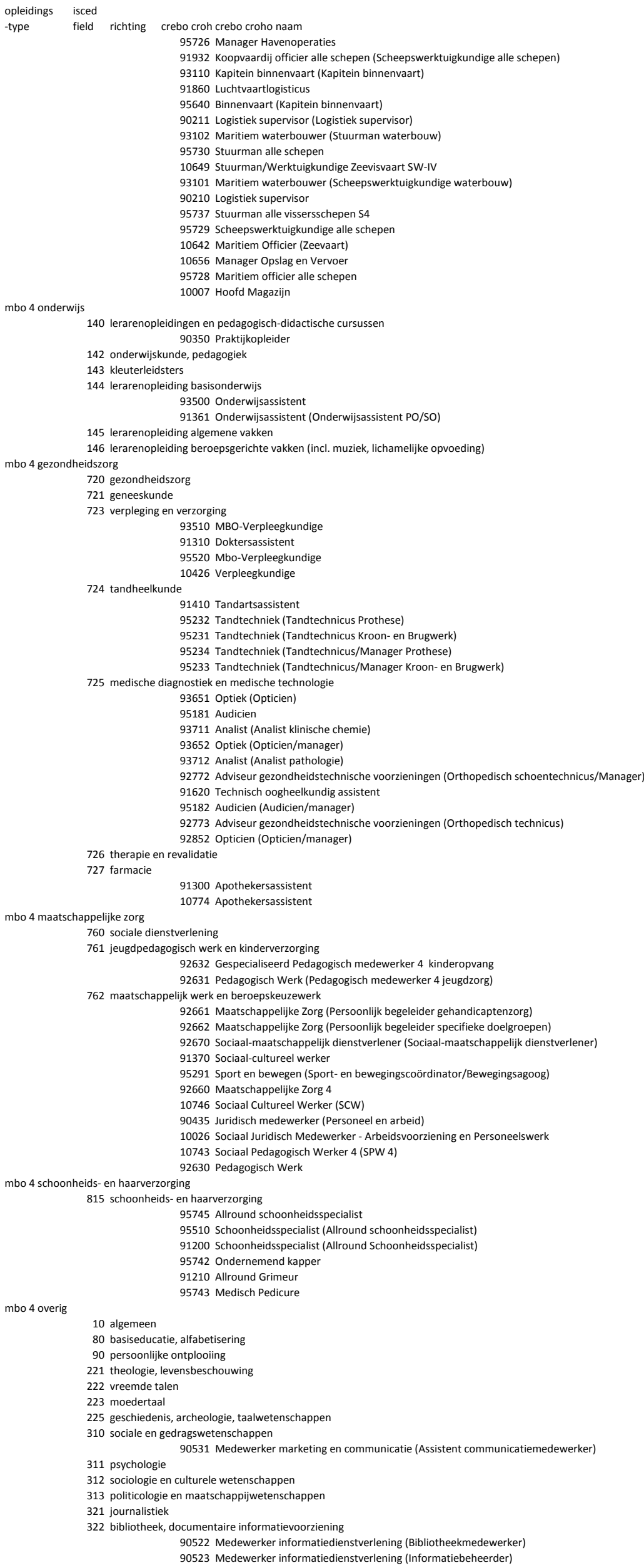

10 algemeen

80 basiseducatie, alfabetisering

90 persoonlijke ontplooiing

221 theologie, levensbeschouwing

222 vreemde talen

223 moedertaal

225 geschiedenis, archeologie, taalwetenschappen

310 sociale en gedragswetenschappen

90531 Medewerker marketing en communicatie (Assistent communicatiemedewerker)

311 psychologie

312 sociologie en culturele wetenschappen

313 politicologie en maatschappijwetenschappen

321 journalistiek

322 bibliotheek, documentaire informatievoorziening 90522 Medewerker informatiedienstverlening (Bibliotheekmedewerker) 
94891 Juridisch medewerker zakelijke dienstverlenin

90434 Juridisch medewerker (Zakelijke dienstverlening)

90433 Juridisch medewerker (Sociale zekerheid)

94890 Juridisch medewerker

10025 Sociaal Juridisch Medewerker - Sociale Zekerheid

90430 Juridisch medewerker

400 wis- en natuurwetenschappen en informatica

420 levenswetenschappen

93713 Analist (Biotechnologisch analist)

93715 Analist (Microbiologisch analist)

97780 Proefdieren (Biotechnicus)

421 biologie en biochemie

441 natuurkunde

442 scheikunde

443 aardwetenschappen

461 wiskunde

700 gezondheidszorg en welzijn

861 openbare orde en veiligheid

862 veiligheid op het werk en ergonomie

863 krijgsmacht

999 onbekend of niet gespecifieerd

hbo leraar basisonderwijs

140 lerarenopleidingen en pedagogisch-didactische cursussen

143 kleuterleidsters

144 lerarenopleiding basisonderwijs

hbo leraar algemene vakke

$$
34808 \text { B Opleiding tot leraar Basisonderwijs }
$$

145 lerarenopleiding algemene vakken

35198 B Opleiding tot leraar voortgezet onderwijs van de tweede graad in Nederland 35195 B Opleiding tot leraar voortgezet onderwijs van de tweede graad in Engels 35197 B Opleiding tot leraar voortgezet onderwijs van de tweede graad in Geschiedenis 35221 B Opleiding tot leraar voortgezet onderwijs van de tweede graad in Wiskunde 35421 B Opleiding tot leraar voortgezet onderwijs van de tweede graad in omgangskunde 35204 B Opleiding tot leraar voortgezet onderwijs van de tweede graad in Pedagogiek 35193 B Opleiding tot leraar voortgezet onderwijs van de tweede graad in Duits 35301 B Opleiding tot leraar voortgezet onderwijs van de tweede graad in Biologie 35201 В Opleiding tot leraar voortgezet onderwijs van de tweede graad in Aardrijkskunde 35196 B Opleiding tot leraar voortgezet onderwijs van de tweede graad in Frans 35411 B Opleiding tot leraar voortgezet onderwijs van de tweede graad in Maatschappijleer 35261 B Opleiding tot leraar voortgezet onderwijs van de tweede graad in Natuurkunde 35261 B Opleiding tot leraar voortgezet onderwijs van de tweede graad in Natuurkunde 35199 B Opleiding tot leraar voortgezet onderwijs van de tweede graad in Scheikunde 35441 B Opleiding tot leraar voortgezet onderwijs van de tweede graad in Godsdienst 35255 B Opleiding tot leraar voortgezet onderwijs van de tweede graad in Spaans 80060 Ad Onderwijsondersteuner Omgangskunde

35205 B Opleiding tot leraar voortgezet onderwijs van de tweede graad in Islamgodsdienst 35144 B Opleiding tot leraar voortgezet onderwijs van de tweede graad in Fries

hbo leraar beroepsgerichte vakken

146 lerarenopleiding beroepsgerichte vakken (incl. muziek, lichamelijke opvoeding) 35025 B Opleiding tot leraar voortgezet onderwijs van de eerste graad in Lichamelijke Opvoeding 39100 B Docent Beeldende Kunst en Vormgeving

35388 B Opleiding tot leraar voortgezet onderwijs van de tweede graad in Gezondheidszorg en Welzijn 35202 B Opleiding tot leraar voortgezet onderwijs van de tweede graad in Algemene Economie 35210 B Opleiding tot leraar voortgezet onderwijs van de tweede graad in het Technisch Beroepsonderwijs 39112 B Docent Muziek

34899 B Educatie en Kennismanagement Groene Sector

35203 B Opleiding tot leraar voortgezet onderwijs van de tweede graad in Bedrijfseconomie

34745 B Docent Theater

34940 B Docent Dans

35423 B Opleiding tot leraar voortgezet onderwijs van de tweede graad in Consumptieve Techniek I en II

35254 B Opleiding tot leraar voortgezet onderwijs van de tweede graad in Techniek

35207 B Opleiding tot leraar voortgezet onderwijs van de tweede graad in Economie

80045 Ad Onderwijsondersteuner Gezondheidszorg en Welzijn

80098 Ad Onderwijsondersteuner Technisch Beroepsonderwijs

39116 B Docent Informatie en Communicatie Technologie

35208 B Opleiding tot leraar voortgezet onderwijs van de tweede graad in Mens en Technologie

80064 Ad Onderwijsondersteuner Educatie en Kennismanagement Groene Sector

80015 Ad Educatie en Kennismanagement Groene Sector Bloemsierkunst

80056 Ad Onderwijsondersteuner Uiterlijke Verzorging

80052 Ad Onderwijsondersteuner Consumptieve Techniek I en II

80051 Ad Onderwijsondersteuner Techniek

80059 Ad Onderwijsondersteuner Zorg \& Welzijn

35484 B Opleiding tot leraar voortgezet onderwijs van de tweede graad in Grafische Techniek I en II

35386 B Opleiding tot leraar voortgezet onderwijs van de tweede graad in Motorvoertuigentechniek I en

35385 B Opleiding tot leraar voortgezet onderwijs van de tweede graad in Mechanische Techniek I en II

210 kunstonderwijs

34951 B Kunst en Economie 50629 B Kunsten, Cultuur en Media

211 beeldende kunst, kunstgeschiedenis

39111 B Vormgeving

39110 B Autonome Beeldende Kunst

56824 B Kunstgeschiedenis

80078 Ad Arts \& Crafts

212 muziek en theater

34739 B Muziek

34798 B Dans

56700 B Muziekwetenschap

56700 B M

34128 B Circus Arts

30014 B Circus and Performance Art

80027 Ad Muziek (dirigent Hafabra)

80085 Ad Dans 
34713 B Kunst en Technie

34733 B Film en Televisie

39279 B Game Architecture and Design

34060 B Mediatechnologie

214 vormgeving

56955 B Industrieel Ontwerpen

34389 B Industrieel Produkt Ontwerpen

39240 B Engineering, Design and Innovation

50441 B Industrial Design

50441 B Industrial Design

34089 B Human Technology

56265 B Technis

39200 B Lifestyle
80018 Ad Industrieel Produkt Ontwerpen

80021 Ad Interieurvormgever

215 kunstnijverheid

hbo communicatie

310 sociale en gedragswetenschappen

34405 B Communicatie

56615 B Communicatiewetenschap

34105 B Media, Informatie en Communicatie

56826 B Communicatie- en Informatiewetenschappen

56631 B Algemene Sociale Wetenschappen

50374 B International Bachelor's Programme in Communication and Media

56837 B Internationale Ontwikkelingsstudies

50429 B Liberal Arts and Sciences: Global Challenges

hbo journalistiek

50016 B Communicatiewetenschappen

EBB 2014 DUO 2013

10.000

34686 B Journalistiek

321 journalistiek

34686 B Journalistiek
322 bibliotheek, documentaire informatievoorziening

34649 B Informatiedienstverlening en -management

80001 Ad Informatiedienstverlening en -management

50010 B Culturele Informatiewetenschap

hbo bedrijfseconomie

maatschappijwetenschappe

56606 B Politicologie

314 economie en econometrie

56833 B Econometrie en Operationele Research

34866 B Bedrijfskunde en Agribusiness

56402 B Fiscale Economie

56402 B Fiscale Econo

30024 B Greenport Business \& Retail

50101 B Economie en Beleid

80043 Ad Ondernemerschap

- 
56994 B Technische Bedriifskunde

56277 B Technologie Managemen

80020 Ad Techishe Bedrifskunde

56836 B Bedrijfs-en Consumentenwetenschappen

80065 Ad Bedrijfseconomie

39233 B Business Engineering

hbo marketing

341 groothandel en detailhandel

34402 B Commerciele Economie

34422 B Small Business en Retail Management

39203 B Vastgoed en Makelaardij

80010 Ad Small Business en Retail Management

81000 B Small Business and Retail Management (open bestel)

34041 B Trade Management gericht op Azie

342 marketing en public relations

34407 B International Business and Languages

80007 Ad Officemanagement

34126 B Commercieel Management

80029 Ad Assistent Marketeer

80036 Ad Marketing Management

hbo accountancy en financiën

80096 Ad Commercieel Management

343 financiële dienstverlening

34414 B Financial Services Management

80093 Ad Financial Services Management

80038 Ad Financiele Dienstverlening

344 financieel management en fiscaal recht

34406 B Accountancy

56827 B Fiscaal Recht

34140 B Fiscaal Recht en Economie

50643 B Accountancy en Controlling

hbo bedrijfskunde en hrm

80008 Ad Accountancy

345 management en personeelswetenschappen

34936 B International Business and Management Studies

34139 B Bedrijfskunde MER

34609 B Human Resource Managemen

50645 B Bedrijfskunde

50952 B International Business Administration

50019 B International Business

34145 B Business Studies

56627 B Bestuurskunde

50007 B Bestuurs- en Organisatiewetenschap

34419 B Europen

34125 B People and Business Management

50627 B Internationale Betrekkingen en Internationale Organisatie

30029 B International Business

56995 B Technische Bestuurskunde

34464 B Bestuurskunde/Overheidsmanagement

56654 B European Public Administration

80074 Ad Bedrijfskunde

34106 B Bedrijfsmanagement MKB

50754 B Organisatiewetenschappen

80080 Ad Ondernemen

80073 Ad Human Resource Management

30016 B Advanced Business Creation

50755 B Personeelwetenschappen

34130 B Business Management

80035 Ad Crossmediale Communicati

34138 B Toegepaste Bedrijfskunde

56869 B Informatie, Multimedia en Management

80028 Ad Bedrijfskunde en Agribusiness

56461 B Recht en Bestuur

80094 Ad Business Management

30017 B Windesheim Honours College

346 secretariële en administratieve ondersteuning

56828 B Notarieel Recht

34121 B Hogere Juridische Opleiding

56829 B Internationaal en Europees Recht

56829 B Internationaal en Europee
50753 B Ondernemingsrecht

50753 B Ondernemings

50620 B Recht en ICT

56475 B Global Law 
55001 B Tourism (joint degree)

30110 B Vitaliteitsmanagement \& Toerisme

80040 Ad Vrijetijdsmanagement

813 sport

34057 B Sport, Gezondheid en Management

34059 B Sport en Bewegingseducatie

34040 B Sport en Bewegen

80026 Ad Sport, Gezondheid en Management

814 huishoudwetenschappen en facilitaire dienstverlening, reiniging

34500 B Facility Management

80004 Ad Facility Management

815 schoonheids- en haarverzorging

hbo informatica

481 informatica

34479 B Informatica

34092 B Communication and Multimedia Design

39118 B Business IT \& Management

30020 B HBO-ICT

34430 B Communicatiesystemen

34475 B Technische Informatica

56978 B Informatica

56964 B Technische Informatica

56981 B Kunstmatige Intelligentie

56842 B Informatiekunde

34131 B Embedded Systems Engineerin

34131 B Embedded Systems

39215 B Bio-informatica

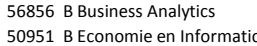

30010 B Information Security Managemen

80083 Ad ICT Service Management

50426 B Computer Science

56983 B Lifestyle Informatics

56573 B Medische Informatiekunde

56066 B Bedrijfsinformatie-technologie

50300 B Kennistechnologie

80014 Ad Business IT \& Management

30015 B Advanced Sensor Applications

80022 Ad Technische Informatica

80071 Ad ICT-Beheer

482 computergebruik

80024 Ad IT Service Management

hbo werktuigbouwkunde

520 techniek en technische dienstverlening

56962 B Technische Natuurkunde

56965 B Technische Wiskunde

34268 B Technische Natuurkunde

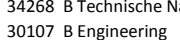

30107 B Engineering
50002 B Advanced Technology

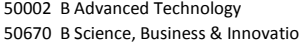

50447 B Creative Technology

39234 B Commercieel Ingenieur

80079 Ad Maintenance \& Mechanics

80091 Ad Engineering

521 werktuigbouwkunde en metaalbewerking

34280 B Werktuigbouwkunde

34280 B Werktuigbouwkunde
56966 B Werktuigbouwkunde

34386 B AOT - Techniek

34386 B AOT - Techniek
80019 Ad Werktuigbouwkunde

80019 Ad Werktuigbouwkunde

525 voertuigtechniek, scheepsbouw- en vliegtuigbouwkunde

56956 B Luchtvaart- en Ruimtevaarttechniek

34262 B Autotechniek

34278 B Luchtvaarttechnologie

56957 B Maritieme Techniek

34276 B Scheepsbouwkunde

30018 B Automotive

hbo elektrotechniek

80067 Ad Maritieme Techniek

522 elektro- en energietechniek

34267 B Elektrotechniek

56953 B Electrical Engineering

80039 Ad Projectleider Techniek

34369 B Energie- en Procestechnologie (AOT)

80017 Ad Elektrotechniek

523 elektronica en industriële automatisering

30026 B Mechatronica

39216 B Industriele Automatisering

56949 B Telematica 


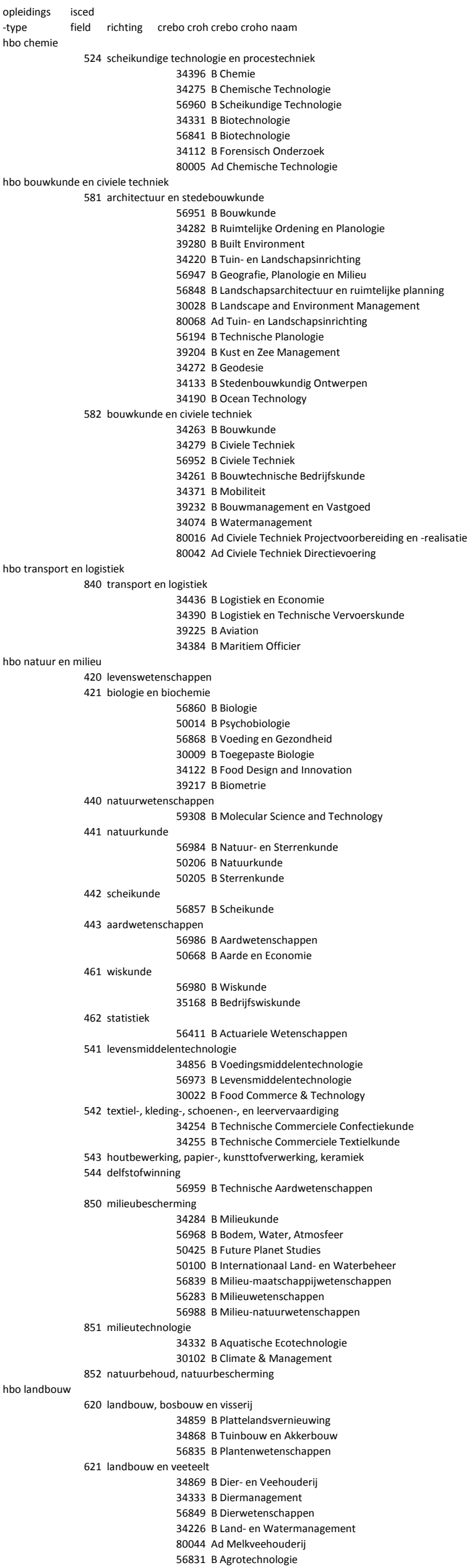




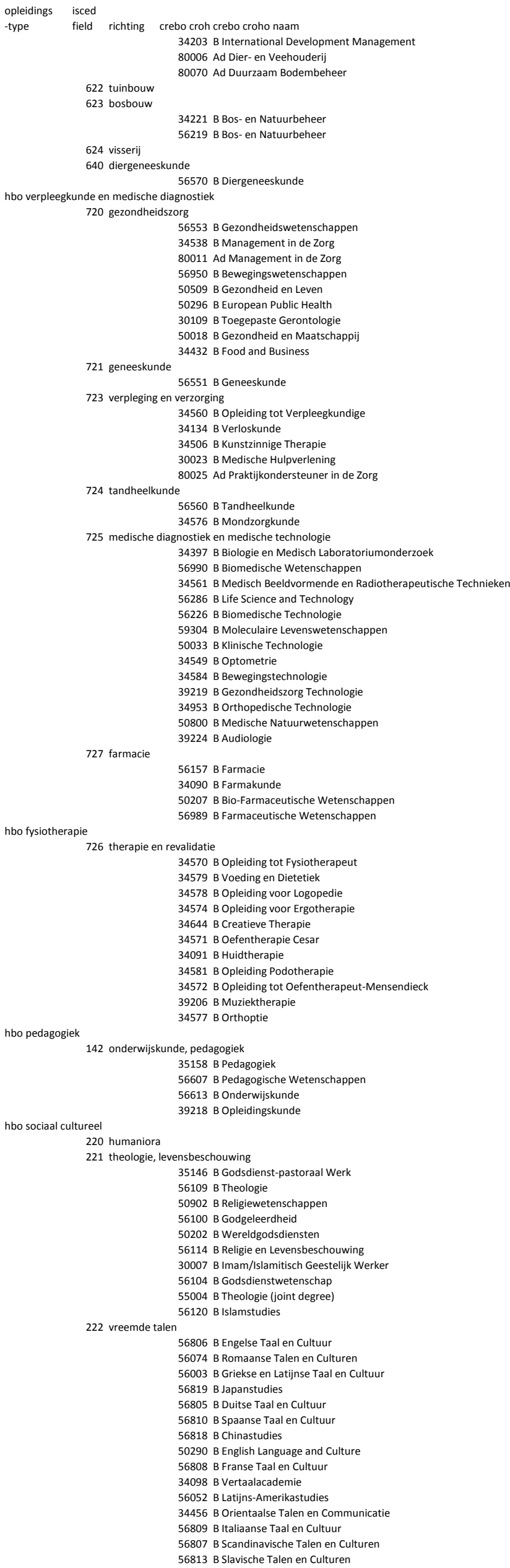


56820 B Koreastudies

56815 B Finoegrische Talen en Culturen

56040 B Arabische Taal en Cultuur

56123 B Oude Culturen van de Mediterrane Wereld

56041 B Islam en Arabisch

56811 B Portugese Taal en Cultuur

56099 B Zuid- en Zuidoost-Aziestudies

80030 Ad Schrijftolk

56814 B Nieuwgriekse Taal en Cultuur

50204 B Vergelijkende Indo-Europese Taalwetenschap

56821 B Afrikaanse talen en culturen

56012 B Minorities \& Multilingualism

56035 B Talen en Culturen van India en Tibet

50901 B Hebreeuwse Taal en Cultuur

50200 B Talen en Culturen van Mesopotamie en Anatolie

50201 B Hebreeuwse en Joodse Studies

223 moedertaal

56804 B Nederlandse Taal en Cultuur

56055 B Nederlandkunde/Dutch Studies

225 geschiedenis, archeologie, taalwetenschappen

56034 B Geschiedenis

56051 B Europese Studies

56801 B Taal- en Cultuurstudies

56803 B Taalwetenschap

34735 B Cultureel Erfgoed

56703 B Archeologie

56802 B Literatuurwetenschap

50623 B American Studies

56098 B Midden-Oostenstudies

39208 B Archeologie

50414 B Film- en Literatuurwetenschap

56704 B Oudheidkunde

56825 B Archeologie en Prehistorie

50855 B Russische Studies

50203 B Ruslandkunde

56124 B Europese Talen en Culturen

226 filosofie en ethiek

56081 B Wijsbegeerte

57084 B Wijsbegeerte van een Bepaald Wetenschapsgebied

311 psychologie

56604 B Psychologie

34507 B Toegepaste Psychologi

312 sociologie en culturele wetenschappen

56601 B Sociologie

56838 B Sociale Geografie en Planologie

50035 B Culturele Antropologie en Ontwikkelingssociologie

56469 B Criminologie

50906 B Media en Cultuur

56823 B Algemene Cultuurwetenschappen

50004 B Cultuurwetenschappe

50004 B Cultuurwetenschappen

hbo matschappelijkwerk

50001 B Theater-, Film- en Televisiewetenschap

760 sociale dienstverlening

761 jeugdpedagogisch werk en kinderverzorging

30012 B Pedagogisch Management Kinderopvan

80081 Ad Pedagogisch Educatief Medewerker

762 maatschappelijk werk en beroepskeuzewerk

34617 B Sociaal Pedagogische Hulpverlenin

34616 B Maatschappelijk Werk en Dienstverlenin

34616 B Maatschappe

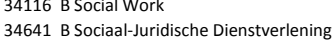

34641 B Sociaal-Juridische Dienstverlening
34610 B Culturele en Maatschappelijke Vormin

34585 B Psychomotorische Therapie en Bewegingsagogie

80086 Ad Ervaringsdeskundige in de Zorg

80090 Ad Sociaal Financiele Dienstverlenin

80032 Ad Intercedent

hbo overig

10 algemeen

80 basiseducatie, alfabetisering

90 persoonlijke ontplooiing

200 kunst en humaniora

50393 B Liberal Arts and Sciences

55002 B Liberal Arts and Sciences (joint degree)

400 wis- en natuurwetenschappen en informatica

30008 B Applied Science

56982 B Natuurwetenschap en Innovatiemanagement 56948 B Science

700 gezondheidszorg en welzijn

999 onbekend of niet gespecifieerd

50250 B Beta-gamma

wo onderwijs

140 lerarenopleidingen en pedagogisch-didactische cursussen 
$60382 \mathrm{M}$ Development and Socialization in Childhood and Adolescence (research) 60212 M Child Development and Education (research)

60749 M Educational Sciences: Learning in Interaction (research)

60159 M Developmental Psychopathology in Education and Child Studies (research)

143 kleuterleidsters

145 lerarenopleiding algemene vakken

68529 M Educatieve master Geesteswetenschappen

68509 M Leraar Voorbereidend Hoger Onderwijs in Maatschappijleer en Maatschappijwetenschappen

$68506 \mathrm{M}$ Leraar Voorbereidend Hoger Onderwijs in Geschiedenis en Staatsinrichting

68512 M Leraar Voorbereidend Hoger Onderwijs in Nederlands

$68502 \mathrm{M}$ Leraar Voorbereidend Hoger Onderwijs in Biologie

$68500 \mathrm{M}$ Leraar Voorbereidend Hoger Onderwijs in Aardrijkskunde

$68404 \mathrm{M}$ Science Education and Communication

$45269 \mathrm{M}$ Leraar Nederlands

45263 M Leraar Wiskunde

$68504 \mathrm{M}$ Leraar Voorbereidend Hoger Onderwijs in Engels

45279 M Leraar Biologie

45267 M Leraar Geschiedenis

$45264 \mathrm{M}$ Leraar Aardrijkskunde

45272 M Leraar Natuurkunde

45262 M Leraar Engels

68517 M Leraar Voorbereidend Hoger Onderwijs in Frans

68519 M Leraar Voorbereidend Hoger Onderwijs in Griekse en Latijnse Taal en Cultuur

45265 M Leraar Duits

45266 M Leraar Fran

60747 M Mens- en Maatschappijonderwijs en Communicatie

68513 M Leraar Voorbereidend Hoger Onderwijs in Scheikunde

68516 M Leraar Voorbereidend Hoger Onderwijs in Wiskunde

45274 M Leraar Godsdienst

$60708 \mathrm{M}$ Communicatie en Educatie van de Natuurwetenschappen

68505 M Leraar Voorbereidend Hoger Onderwijs in Filosofie

68503 M Leraar Voorbereidend Hoger Onderwijs in Duits

68511 M Leraar Voorbereidend Hoger Onderwijs in Natuurkund

45273 M Leraar Scheikunde

$68507 \mathrm{M}$ Leraar Voorbereidend Hoger Onderwijs in Godsdienst en Levensbeschouwing

68514 M Leraar Voorbereidend Hoger Onderwijs in Spaans

45268 M Leraar Maatschappijleer

60614 M Educatie en Communicatie in de Wiskunde en Natuurwetenschappen

$68508 \mathrm{M}$ Leraar Voorbereidend Hoger Onderwijs in Kunstgeschiedenis en Culturele en Kunstzinnige Vorming/Kunst Algemeen

$60635 \mathrm{M}$ Opleiding tot leraar voortgezet onderwijs van de eerste graad in Geschiedenis

$60632 \mathrm{M}$ Opleiding tot leraar voortgezet onderwijs van de eerste graad in Engelse Taal en Cultuur

$60238 \mathrm{M}$ Opleiding tot leraar voortgezet onderwijs van de eerste graad in Filosofie

44104 M Opleiding Dovenstudies/Masteropleiding Leraar Nederlandse Gebarentaal

45124 M Leraar Spaans

60204 M Opleiding tot leraar voortgezet onderwijs van de eerste graad in Aardrijkskunde

$60636 \mathrm{M}$ Opleiding tot leraar voortgezet onderwijs van de eerste graad in Griekse en Latijnse Taal en Cultuur

$60637 \mathrm{M}$ Opleiding tot leraar voortgezet onderwijs van de eerste graad in Nederlandse Taal en Cultuur

$60403 \mathrm{M}$ Opleiding tot leraar voortgezet onderwijs van de eerste graad in Religie in Samenleving en Cultuur

68521 M Leraar Voorbereidend Hoger Onderwijs in Arabisch

$60633 \mathrm{M}$ Opleiding tot leraar voortgezet onderwijs van de eerste graad in Franse Taal en Cultuur

$60631 \mathrm{M}$ Opleiding tot leraar voortgezet onderwijs van de eerste graad in Duitse Taal en Cultuur

$60231 \mathrm{M}$ Mathematics and Science Education

$60320 \mathrm{M}$ Opleiding tot leraar voortgezet onderwijs van de eerste graad in Spaanse Taal en Cultuur

$60243 \mathrm{M}$ Opleiding tot leraar voortgezet onderwijs van de eerste graad in Maatschappijleer

146 lerarenopleiding beroepsgerichte vakken (incl. muziek, lichamelijke opvoeding)

49117 M Kunsteducatie

45275 M Leraar Algemene Economic

68501 M Leraar Voorbereidend Hoger Onderwijs in Algemene Econom

$68518 \mathrm{M}$ Leraar Voorbereidend Hoger Onderwijs in Management en Organisatie

45271 M Leraar Bedrijfseconomie

$60651 \mathrm{M}$ Opleiding tot leraar voortgezet onderwijs van de eerste graad in Economie en Bedrijfswetenschappen

49501 M Kunsteducatie (joint degree)

60701 M Kunstonderwijs en Communicatie

68510 M Leraar Voorbereidend Hoger Onderwijs in Muziek

210 kunstonderwiis

60087 M Kunst- \& cultuurwetenschappen

60829 M Kunst- \& cultuurwetenschappen (research)

60629 M Kunsten, Cultuur en Media

60768 M Study of Art and Literature (research)

60182 M Kunstwetenschappen (research)

60295 M Kunst en Visuele Cultuur in Historisch Perspectief (research)

211 beeldende kunst, kunstgeschiedenis

44853 M Autonome Beeldende Kunst

44759 M Vormgeving

44759 M Vormgeving

$60639 \mathrm{M}$ Art History and Archaeology: Material Culture Studies in Art, Architecture and Archaeology (research)

44749 M Vrije Vormgeving

49113 M MFA Schilderkunst

60758 M Art History of the Low Countries in its European Context (research) 
44739 M Muziek

44852 M Master of Music

49103 M Choreografie

49104 M Sonologie

49105 M Opera

44874 M Theater

60193 M Dramaturgie

49114 M MFA Theatervormgeving/Beeldregie

213 audiovisuele techniek en mediaproductie

44758 M Grafisch Ontwerpen

44733 M Film

49107 M Media Design and Communication

49106 M Type and Media

49101 M Typografie

44756 M Fotografie

60140 M Film and Photographic Studies

214 vormgevin

$60029 \mathrm{M}$ Industrial Engineering and Management

60354 M Integrated Product Design

60356 M Strategic Product Design

$60355 \mathrm{M}$ Design for Interaction

60441 M Industrial Design

66955 M Industrial Design Engineering

$49238 \mathrm{M}$ Interieurarchitectuur

60431 M Human-technology Interaction

44760 M Interior Architecture \& Retail Design

44804 M Fashion Strategy

215 kunstnijverheid

221 theologie, levensbeschouwing

60824 M Theologie \& Religiewetenschappe

$60257 \mathrm{M}$ Theologie

66114 M Religie en Levensbeschouwing

60827 M Theologie \& Religiewetenschappen (research)

$60502 \mathrm{M}$ Interreligieuze spiritualiteitsstudies

66100 M Godgeleerdheid

60254 M Theology

66109 M Godgeleerdheid

60601 M Geestelijke Verzorgin

66118 M Religion and Theology (research)

$60131 \mathrm{M}$ Religiestudies

66104 M Godsdienstwetenschap

60195 M Religiewetenschappen (research)

66120 M Islamic Theology

222 vreemde talen

60839 MAzlestudes

60174 M Latijns-Amerika Studies

60174 M Latijns-Ame

60840 M Azie Studies

66806 M Engelse Taal en

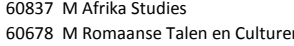

60838 M Afrika Studies (research)

$66041 \mathrm{M}$ Islam en Arabisch

60152 M Latin American and Caribbean Studies (research)

66809 M Italiaanse Taal en Cultuur

60673 M Engelse Taal en Cultuur

60188 M Nederlands als tweede Tal

60188 MNederlands als tweede Taal

66052 M Talen en Culturen van Latijns Amerika/Spaans

60841 M Azie Studies (research)

66003 M Griekse en Latijnse Taal en Cultuu

60844 M Latijns-Amerika Studies (research)

60150 M African Studies (research)

66015 M Egyptische Taal en Cultuur

66016 M Arabische, Nieuwperzische en Turkse Talen en Culture

$66035 \mathrm{M}$ Indian and Tibetan Studies

66808 M Franse Taal en Cultuur

$66022 \mathrm{M}$ Indonesian Studies

223 moedertaal

66819 MTalen en Culturen van Japan

60849 M Neerlandistiek

60850 M Neerlandistiek

66804 M Nederlandse Taal en Cultuu

60677 M Nederlandse Taal en Cultuur

60851 M Neerlandistiek (research)

60189 M Nederlandse Letterkunde (research)

60764 M Nederlandse Literatuur (research)

225 geschiedenis, archeologie, taalwetenschappen

$66034 \mathrm{M}$ Geschiedenis

60815 M Taalwetenschappen

60813 M Letterkunde

69303 M European Studies

60284 M Europese Studies

60805 M Archeologie

60845 M Noord-Amerika Studies

60139 M Geschiedenis (research)

60740 M Talenonderwijs en Communicatie

60817 MTaalwetenschappen (research)

60821 M Oudheidstudies

60814 M Letterkunde (research)

60847 M Europese Studies

60842 M Midden-Oosten Studies

60835 M Erfgoedstudies

$60335 \mathrm{M}$ Conservering en Restauratie van Cultureel Erfgoed

$60039 \mathrm{M}$ Oudheidstudies (research)

60298 M History: Societies and Institutions (research) 


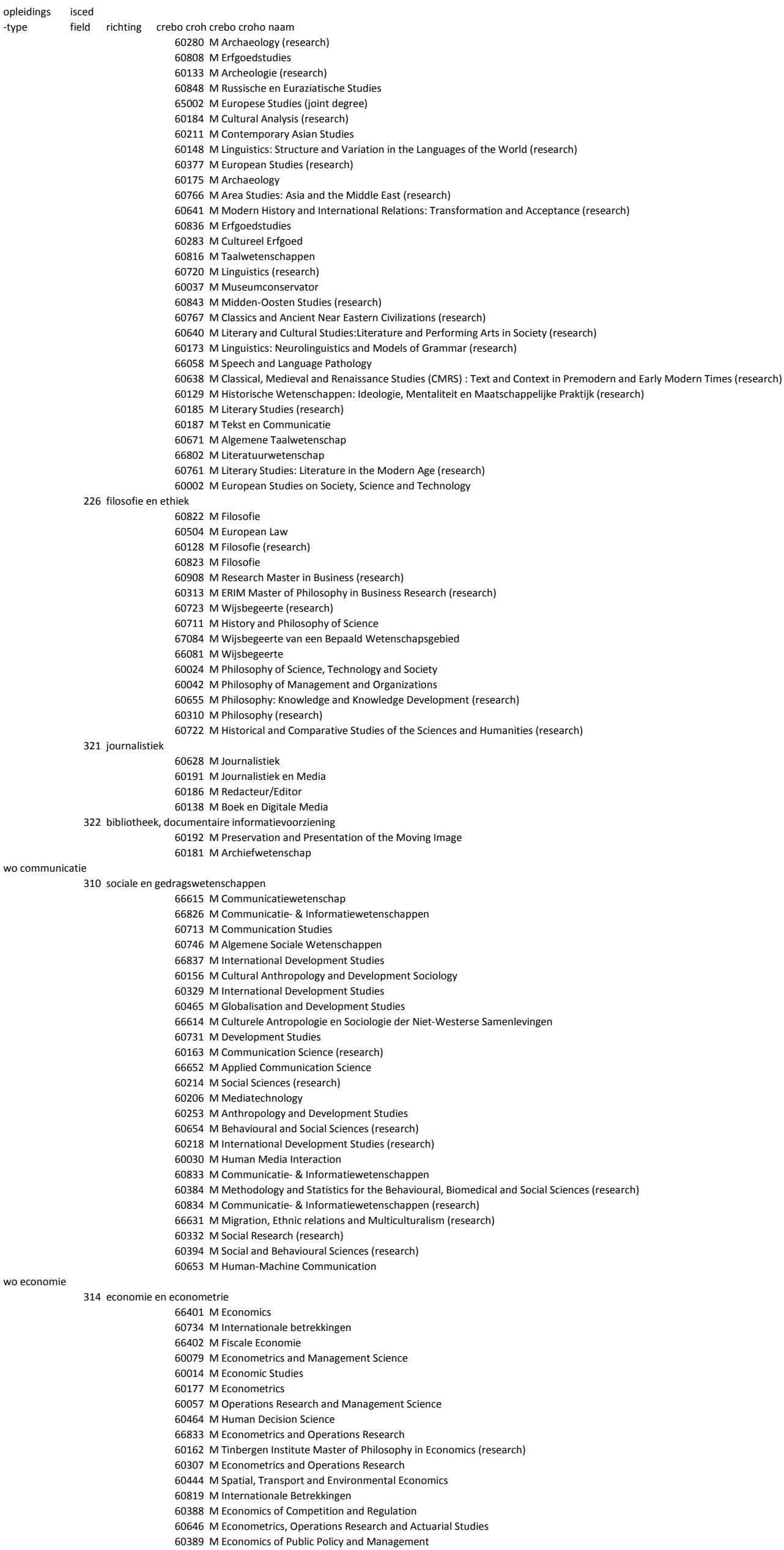


811 horeca

$60018 \mathrm{M}$ Information and Network Economics

wo bedrijsseconomie

340 bedrijfskunde en administratie

$60652 \mathrm{M}$ Economics and Business

60901 M Business Economic

66836 M Management, Economics and Consumer Studies

$60648 \mathrm{M}$ International Economics and Business

66430 M Operations Management and Logistics

$66277 \mathrm{M}$ Technology and Operations Management

$60315 \mathrm{M}$ Research Master in Economics and Business (research)

341 groothandel en detailhandel

$60659 \mathrm{M}$ Vastgoedkunde

342 marketing en public relations

60063 M Marketing Management

60048 M Marketing

60064 M Marketing Research

840 transport en logistiek

60093 M Supply Chain Management

60361 M Transport, Infrastructure and Logistics

60445 M Global Supply Chain Management and Change

wo accountancy en financiën

343 financiële dienstverlening

60046 M Finance

60409 M Finance \& Investments

60321 M Financial Economics

60449 M Aansprakelijkheid en verzekering

344 financieel management en fiscaal recht

66827 M Fiscaal Rech

60059 M Accounting

$60900 \mathrm{M}$ Accountancy and Control

60047 M Accounting and Control

60643 M Accountancy and Controlling

60633 M Accountancy and Controlling

60683 M International Financial Management

60459 M International and European Tax Law

60686 M International Business Taxation

wo bedrijfskunde en $\mathrm{hrm}$

345 management en personeelswetenschappen

60644 M Business Administration

$60019 \mathrm{M}$ International Busines

60902 M Business Studies

60066 M Strategic Management

60020 M Public Administration

$66627 \mathrm{M}$ Bestuurskunde

60052 M Beleid, Communicatie en Organisati

60446 M Bestuurs- en Organisatiewetenschap

$44135 \mathrm{M}$ Leren en Innoveren

60754 M Organisation Studies

60645 M Human Resource Management

$60649 \mathrm{M}$ International Business and Management

$60050 \mathrm{M}$ Culture, Organization and Management

60075 M Human Resource Studies

60328 M Public Policy and Human Development

$60430 \mathrm{M}$ Innovation Management

60458 M Management of Innovation

$60256 \mathrm{M}$ International Management

60457 M Organisational Change \& Consulting

60455 M Entrepreneurship \& New Business Venturing

60407 M International Management

60456 M Global Business \& Stakeholder Management

60448 M International Public Management and Public Policy

44136 M Learning \& Innovation

60001 M Management of Learning

$60627 \mathrm{M}$ Internationale Betrekkingen en Internationale Organisatie

60416 M Management Publieke Sector

60454 M Chinese Economy \& Business

$66265 \mathrm{M}$ Innovation Sciences

$60391 \mathrm{M}$ Research in Public Administration and Organizational Science (research)

66461 M Recht en Bestuur

60003 M European Public Affairs

60013 M Business Research (research)

60114 M Cultuurbeleid,-beheer en -behoud

346 secretariële en administratieve ondersteuning

60220 M Publiekrecht

60085 M Bedrijfsrecht

60222 M Arbeidsrecht

60452 M Commercial Law

60017 M European Law School

60418 M Forensische Criminolog

$60408 \mathrm{M}$ Ondernemingsrecht

60171 M Forensica, Criminologie en Rechtspleging

$60072 \mathrm{M}$ International Business Law

$60741 \mathrm{M}$ Recht en onderneming

590

150

130

80

60
20

- $\quad 40$

14.500 
$60223 \mathrm{M}$ Informatierecht

60169 M Recht en Arbeid

60685 M Law and Politics of International Security

60451 M Recht van de Gezondheidszorg

$60073 \mathrm{M}$ International and European Public Law

60602 M European Law

$60602 \mathrm{M}$ European Law
$60069 \mathrm{M}$ Law and Technology

$60069 \mathrm{M}$ Law and $\mathrm{T}$.

60419 M Criminaliteit en Rechtshandhavin

$60742 \mathrm{M}$ Law and Economics

60168 M International Laws

$60605 \mathrm{M}$ International Law and the Law of International Organizations

$60604 \mathrm{M}$ International Economic and Business Law

60606 M Functionaliteit van het Recht (research)

66829 M Internationat en Europees recht

60744 M Legal Research (research)

60412 M European Private Law

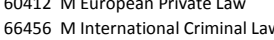

60393 M Research Master in Law (research)

60450 M Togamaster

60620 M Recht en ICT

60386 M Onderneming en Recht (research)

60369 M Public International Law (research)

$60603 \mathrm{M}$ International and Comparative Private Law

$60366 \mathrm{M}$ Information Law (research)

861 openbare orde en veiligheid

60417 M Crisis and Security Management

862 veiligheid op het werk en ergonomie

60453 M Business Information Management

60300 M Computer Science

66978 M Informatica

60229 M Information Studies

$60331 \mathrm{M}$ Embedded Systems

66981 M Artificial Intelligence

$60055 \mathrm{M}$ Information Management

$60228 \mathrm{M}$ Software Engineering

$60255 \mathrm{M}$ Information Sciences

60809 M Information Scien

60205 M ICT in Business

$60227 \mathrm{M}$ System and Network Engineering

$60108 \mathrm{M}$ Geo-information Science

60323 M Brain and Cognitive Sciences (research)

60106 M Bioinformatics

60025 M Business Information Technology

60432 M Business Information Systems

$60347 \mathrm{M}$ Industrial and Applied Mathematics

$60364 \mathrm{M}$ Computing Science

66856 M Business Analytics

66573 M Medical Informatics

60299 M Computational Science

$60951 \mathrm{M}$ Economics and Informatics

$66842 \mathrm{M}$ Informatiekunde

44714 M MFA Interactive Media and Environments

482 computergebruik

520 techniek en technische dienstverlening

60436 M Applied Physics

60358 M Systems Engineering, Policy Analysis and Management

60710 M Natuurwetenschappen en Bedrijf

60803 M Management, Policy Analysis and Entrepreneurship in the Health and Life Sciences

$66995 \mathrm{M}$ Management of Technology

60179 M Engineering and Policy Analysis

60709 M Science and Innovation

60028 M Nanotechnology

521 werktuigbouwkunde en metaalbewerking

$66958 \mathrm{M}$ Materials Science and Engineering

$60353 \mathrm{M}$ Electrical Engineering

$60608 \mathrm{M}$ Energy and Environmental Sciences

523 elektronica en industriële automatisering

60438 M Computer Science and Engineering

60359 M Systems and Control

$60351 \mathrm{M}$ Computer Engineerin

60802 M Parallel and Distributed Computer Systems

60032 M Telematics

60027 M Mechatronics 


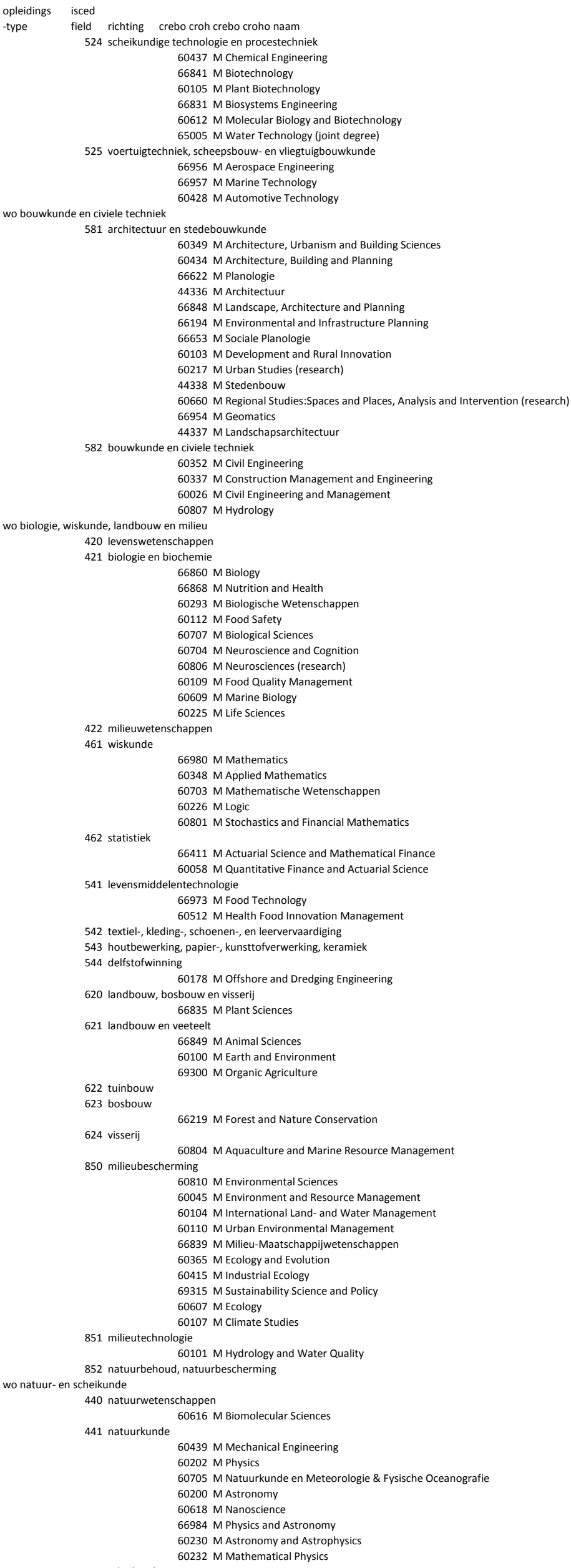

440 natuurwetenschappen

60616 M Biomolecular Sciences

441 natuurkunde

60439 M Mechanical Engineering 60202 M Physics

60705 M Natuurkunde en Meteorologie \& Fysische Oceanografie

60200 M Astronomy

60618 M Nanosci

$66984 \mathrm{M}$ Physics and Astronomy

60230 M Astronomy and Astrophysics

60232 M Mathematical Physics

442 scheikunde 
66986 M Earth Sciences

$65000 \mathrm{M}$ Geosciences of Basins and Lithosphere (research) (joint degree)

wo (dier)geneeskunde en tandheelkunde

640 diergeneeskund

66570 M Diergeneeskunde

721 geneeskund

66551 M Geneeskund

6551 Geneeskunde

49115 M Physician Assistant

66583 M Geneeskunde, klinisch onderzoeker

66585 M Arts - Klinisch Onderzoeker

60811 M Oncology

$60375 \mathrm{M}$ Infection and Immunity (research)

724 tandheelkunde

$60375 \mathrm{M}$ Infection and Immunity (research
$60312 \mathrm{M}$ Clinical Research (research)

66588 M Tandheelkunde

$66560 \mathrm{M}$ Tandheelkunde

wo gezondheidszor

720 gezondheidszor

$66851 \mathrm{M}$ Health Sciences

60076 M Psychologie en Geestelijke Gezondheid

60081 M Zorgmanagement

66950 M Human Movement Sciences: Sport, Exercise and Health

$60082 \mathrm{M}$ Health Economics, Policy and Law

$66902 \mathrm{M}$ Global Health

$60460 \mathrm{M}$ Healthcare Policy, Innovation and Management

$60006 \mathrm{M}$ Mental Health

60461 M Health Education and Promotion

60054 M Bewegingswetenschappen

60684 M Human Movement Science

60812 M Human Movement Sciences: Sport, Exercise and Health (research)

$60120 \mathrm{M}$ Health Sciences (research)

60380 M Social \& Health Psychology (research)

60379 M European Public Health

$60463 \mathrm{M}$ Sports and Physical Activity Intervention

60011 M Epidemiology

60368 M Lifestyle and Chronic Disorders (research)

60007 M Work, Health and Caree

$60399 \mathrm{M}$ Clinical and Psychosocial Epidemiology (research)

$66903 \mathrm{M}$ Global Health (research)

723 verpleging en verzorging

49246 M Advanced Nursing Practice

66563 M Klinische Gezondheidswetenschappen

725 medische diagnostiek en medische technologie

$66990 \mathrm{M}$ Biomedical Sciences

$66226 \mathrm{M}$ Biomedical Engineering

60121 M Cognitive and Clinical Neuroscience (research)

60033 M Technical Medicine

66286 M Life Science and Technology

60506 M Cognitive Neuroscience (research)

60303 M Molecular Life Sciences

60610 M Medical Biology

60462 M Bewegingswetenschappen

69304 M Moleculaire Levenswetenschappen

$60615 \mathrm{M}$ Behavioural and Cognitive Neurosciences (research)

$60322 \mathrm{M}$ Molecular Mechanisms of Disease (research)

60344 M Medical Engineering

$60800 \mathrm{M}$ Medical Natural Sciences

60279 M Molecular Medicine (research)

66586 M Cardiovascular Research (research)

60278 M Neuroscience (research)

726 therapie en revalidatie

66577 M Logopediewetenschap

727 farmacie

66157 M Farmacie

60207 M Bio-Pharmaceutical Sciences

66989 M Drug Discovery and Safety

60294 M Pharmaceutical Sciences

60611 M Medical Pharmaceutical Sciences

60617 M Medical and Pharmaceutical Drug Innovation

wo politicologie en sociologie

312 sociologie en culturele wetenschappen

60830 M Mediastudies

66601 M Sociologie

66620 M Sociale Geografie

66469 M Criminologie

60466 M Human Geography

60745 M Culturele Antropologie

60198 M Medische Antropologie en Sociologi

60049 M Social and Cultural Anthropology

66725 M Victimology and Criminal Justice

66724 M International Crimes and Criminology

66599 M Sociology

60832 M Mediastudies (research)

60657 M Economische Geografie

$60658 \mathrm{M}$ Population Studies

60732 M Geographical Sciences

60656 M Culturele Geografie

60378 M Cultural Anthropology: Sociocultural Transformation (research)

60132 M Social and Cultural Science: Comparative Research on Societies (research)

60748 M Sociology and Social Research (research)

60166 M Human Geography and Planning (research)

60669 M Criminal Law and Criminology 
66702 M Film- en Televisiewetenschap

$60370 \mathrm{M}$ Sociology of Culture, Media and the Arts (research)

313 politicologie en maatschappijwetenschappen

66606 M Politicologie

60203 M Political Science

$69314 \mathrm{M}$ Conflict Resolution and Governance

$60421 \mathrm{M}$ Political Science and Public Administration (research)

60421 M Pollical Science and Public Adm

60500 M European Union Studies

812 toerisme en vrijetijdsbesteding

60111 M Leisure, Tourism and Environmen

813 sport

60078 M Leisure Studies

60682 M Sport Sciences

814 huishoudwetenschappen en facilitaire dienstverlening, reiniging

815 schoonheids- en haarverzorging

wo psychologie en maatschappelijk werk

311 psychologie

66604 M Psycholo

60260 M Psychologie

60216 M Gezondheidszorgpsychologie

60077 M Social Psychology

60383 M Psychology (research)

66581 M Medische Psychologie

$60266 \mathrm{M}$ Behavioural Science (research)

69305 M Forensic Psychology

60510 M Cognitive Neuropsychology (research)

60053 M Social Psychology: Regulation of Social Behaviour (research)

60053 M Social Psychology: Regulation of Social Behaviour (research)

40513 M Clinical and Dev M Danstherapie

761 jeugdpedagogisch werk en kinderverzorging

40019 M Jeugdzorg

762 maatschappelijk werk en beroepskeuzewerk

44116 M Social Work

49500 M Social Work (joint degree)

wo overig

10 algemeen

80 basiseducatie, alfabetiserin

90 persoonlijke ontplooiing

00 kunst en humanior

400 wis- en natuurwetenschappen en informatica 60338 M Forensic Science

66982 M Science

700 gezondheidszorg en welzijn

40101 M Health Care and Social Work

999 onbekend of niet gespecifieerd

60626 M Humanitarian Action

999 onbekend of niet gespecifieerd 